\title{
Târîh-i Osmânî Encümeni Kurucularından Efdaleddin (Tekiner) Beyin Hayatı, Eserleri ve Tarihçiliği Üzerine
}

EYÜP BAS

Dr., ANKARA Ü. İLÂHIYAT FAKÜLTESI

e-mail: bas@ divinity.ankara.edu.tr

\begin{abstract}
Life, Works and Historical Views of Efdaleddin (Tekiner) Bey, One of the Founders of Council of the Ottoman History. This study discusses life, works and historical views of Efdaleddin Bey, who was one of the founding members of the Council of the Ottoman History (Târîh-i Osmânî Encümeni), which contributed to inception of historical studies in the contemporary sense in the Ottoman era. In addition to his official duties, Efdaleddin Bey taught history and geography in a number of schools. His national historical awareness was very strong. He always advocated preservation of all material and intangible cultural values of the Ottoman era, and he assumed various positions in governmental and non-governmental organization working in this field. In the republic era, he served as a member of the Turkish Historical Society for an extended period. His works are remarkable in that they served as the precursors of scientific methods with respect to the way historical materials are evaluated, resourced are used and documents are handled,
\end{abstract} etc.

key words

Efdaleddin (Tekiner) Bey, Council of the Ottoman History (Târîh-i Osmânî Encümeni), Ottoman historical studies, Turkish Historical Society

\section{SUNUS}

Tarih, konusu itibariyle pek çok insanı gerek okur gerekse yazar olarak kendisine çekmiş bir bilim dalıdır. Bu bilim dalı çerçevesinde gerçekleşen faaliyete yalnızca okur olarak katkı sağlamış olanların ya da okuduklarını sözlü olarak kullanıp birilerine aktarmakla yetinmiş olanların bir dereceye kadar zihinlerde yer etmemiş olmaları doğaldır. Kanaatimizce tarihi yapanların ve 
yazanların unutulmaları ise o kadar kolay olmamalıdır. Özellikle tarihî bilgilerin nesilden nesile aktarılmasında en önemli rolü üstlenen tarih yazarlarının -aralarında tarihçilik anlayışı bakımından farklılıklar olmakla birlikte- dikkate alınması bir zorunluluk gibidir. Eserleri ayırım yapılmaksızın gerek içerik gerekse metot bakımından incelenmek durumundadır. Ancak bu gerçekleştirilirse, birbirlerinden farklı yönleri ortaya çıkarılabilir ve bir milletin tarihçiliği bütün halinde ele alınabilir.

Bilindiği gibi Osmanlı tarih literatürü oldukça zengindir. İçerisinde oldukça farklı tür ve tarzda kaleme alınmış tarih eserlerini barındırır. Her ne kadar günümüz şartlarındaki gibi bir alanda ihtisaslaşma olmasa da, Osmanlı tarihçileri dediğimiz insanlar, kişisel merakları ya da görevleri gereği söz konusu tarih literatürünün oluşumuna katkı sağlamışlardır.

İşte bunlardan birisi, Osmanlı tarihçiliğinin artık belli bir düzeye geldiğii, hatta çağdaş anlamda kurumsallaşma gösterdiği bir dönemde yaşamış ve aktif olarak söz konusu faaliyetlerde yer almış olan Efdaleddin Bey'dir. Târîh-i Osmânî Encümeni'nin ${ }^{1}$ kurucu üyelerinden, aynı zamanda bu kurumun Cumhuriyetin ilanından sonra Türk Tarih Kurumu'na ${ }^{2}$ dönüştürülmesiyle yine üyeliği devam eden şahsiyetlerinden biridir. Hakkında çok az şey bilinen Efdaleddin Bey'i özellikle tarih alanındaki çalışmaları ve tarihçiliğini bir makale konusu yapmayı uygun bulduk. Bu çalışmamızda, hayatını gerçekten tarih öğrenmek, öğretmek ve yazmakla, hatta Eski Eserleri Koruma Derneği'nin bir üyesi ve başkanı sıfatıyla, ecdad yadigârları üzerine kolkanat germekle geçirmiş olan Efdaleddin Bey'in biyografisini, eserlerini, ilmî kişiliğini, tarih anlayışı ve tarihçiliğini ortaya koymaya çalışacağız.

\section{HAYATI}

Efdaleddin Bey'in resmi hayatı ile ilgili ilk elden bilgileri, Sicill-i Ahvâl Defteri'ndeki ${ }^{3}$ kayıtlardan ve Emekli Sandı $\breve{g ̆}_{1}$ Arşivi'ndeki $^{4}$ sicil dosyasından elde etmekteyiz. Ayrıca onun, Mülkiye tarihine ilişkin bir çalışma hazırladığ1 sırada Mücellitoğlu Ali Çankaya'ya verdiği otobiyografisini ${ }^{5}$ de, hayatı hakkında önemli bir bilgi kaynağı olarak göz önünde bulundurmak gereklidir.

1 Bu encümen hakkında genişbilgi için bkz. Mehmet Demiryürek, “Tarih-i Osmanî Encümeni'nin Kuruluşu", Toplumsal Tarih, c. XV, S. 90, Haziran 2001, s. 41-49.

2 Türk Tarih Kurumu hakkında geniş bilgi için bkz. Fahri Çoker, Türk Tarih Kurumu, Kuruluş Amacı ve Çalışmaları, Ankara, 1983.

3 Bașbakanlık Osmanlı Arșivi (BOA), Sicill-i Ahvâl Defteri, Nr: 71, s. 83-84 ve Nr: 180, s. 149.

4 Emekli Sandığı Arşivi, MO/115923 Numaralı Sicil Dosyası.

5 Bkz. Mücellitoğlu Ali Çankaya, Mülkiye Tarihi ve Mülkiyeliler, Ankara, 1968-1969, II, 259260. Ayrica bkz. III, 517-520. 
Söz konusu kaynaklara göre Efdaleddin Bey, 1868'de İstanbul Cerrahpaşa'da doğmuştur. Babası Zabtiye Nâzırı Hacı Hâfız Paşa'nın oğlu Hazîne-i Hassa Umûmî müfettişi İsmail Cevad Bey'dir. Validesi, Maraş’ın Beyazıdzâde ailesinden meşhur şair ve münşî Âmedci Kenan Bey'in kızı Emine Yegâne Hanım'dır. Çocukluk yıllarına dair elimizde pek bilgi bulunmayan Efdaleddin Bey, yeni usül mektebi olarak kurulan Süleymaniye İbtidaî Mektebi'nde ilk; Beyazıd Kaptanpaşa Rüştiyesi'nde orta; Mülkiye Mektebi İdâdî Kısımı'nda da lise öğrenimini tamamlayarak 1893'de Yüksek Kısımı'ndan mezun olmuştur. 24 Mart 1894'de Dâhiliye Nezâreti Mektubî Kalemi Halîfeliği ile memuriyet hayatına girmiş olan Efdaleddin Bey, bir süre sonra Sadaret Âmedi-i Divânı Hümâyûn Kalemi'ne ${ }^{6}$ geçmiştir.7 1896 'dan itibaren birçok okulda da öğretmen olarak görevlendirilmiştir.

Efdaleddin Bey 1910'da, asıl memuriyeti olan Sadâret Âmed-i Hümâyûn Kalemi hulefâlığından, Dâhiliye Nezâreti Muhâberât-1 Umûmiye İdâresi 3. Şube Müdürlügüne atanmıştır. ${ }^{8}$ Bu arada hizmet cedvelinde yer almayan, ancak otobiyografisinde belirttiği bazı görevlendirmeleri söz konusudur. Buna göre Efdaledin Bey, 7 Temmuz 1911'de Donanma Muâvenet-i Milliye Cemiyeti Komiserliği; 15 Eylül 1911'de yeni kurulan Târîh-i Osmânî Encümeni daimî azalığı; 24 Mart 1912'de Dârülfünûn Müntehap âzası olarak Meclis-i Kebîr-i Maârif Âzalığ ${ }_{1}$ ile görevlendirilmiştir. ${ }^{9}$

Daha sonra 22 Eylül-3 Kasım 1912 tarihleri arasında çok kısa bir süre Bursa Vali Vekilliği yapmıştır. ${ }^{10} 29$ Ekim 1913'de Dâhiliye Nezâreti Mebânii Emîriyye (Resmî Binalar) ve Hapishaneler Umûm Müdürü olarak atanmıştır. Görevde bulunduğu sürede İstanbul Tevkifhânesi, Üsküdar ve Bursa Hapishânelerini yaptırdığını belirtmiştir. ${ }^{11}$ İstanbul hükümetinin ilgasına kadar bu görevde kalmış olan Efdaleddin Bey, 20 Mart 1922'de TBMM Hükümetince eski İstanbul Hükümetinin İstanbul'daki Muâmelâtını Tasfiye Komisyonu azalığına getirilmiş, 26 Mayıs 1923'de tekrar Dâhiliye Vekâleti

6 Gerek sadrazamın padişaha yazacağı telhîs ve takrîrler, gerekse yabancı devletlere yazılan her çeşit yazının hazırlandığı Âmedî Kalemi hakkında geniş bilgi için bkz. Efdalüddin (Tekiner), "Âmedci, Âmedî", İslâm Türk Ansiklopedisi, İstanbul, 1942, I, 370; İsmail Hakkı Uzunçarşıll, Osmanlı Devletinin Merkez ve Bahriye Teşkilatı, Ankara, 1988, s. 55-58; Tayyip Gökbilgin, "Âmedci", İA., İstanbul, 1950, I, 396-397; M.Zeki Pakalın, Osmanlı Tarih Deyimleri ve Terimleri Sözlüğü, İstanbul, 1993; I, 55-56; Necati Aktaş, “Âmedci”, DİA, İstanbul 1991, III, 12.

7 BOA, Sicill-i Ahvâl Defteri, Nr: 71, s. 83.

8 BOA, Sicill-i Ahvâl Defteri, Nr: 71, s. 84

9 M. A. Çankaya, Mülkiye Tarihi ve Mülkiyeliler, II, 260; Fahri Çoker, Türk Tarih Kurumu, Kuruluş Amact ve Çalışmaları, s. 500-501.

10 BOA, Sicill-i Ahvâl Defteri, Nr: 180, s. 149.

11 Bkz. M. A. Çankaya, Mülkiye Tarihi ve Mülkiyeliler, II, 260. 
Resmî Binalar ve Hapishaneler Umum Müdürü olarak atanmıştır. Bir yıl sonra ise, Ermeni zenginlerinden Benon Değirmenciyan'ın mübâdeleye tutulmayıp İstanbul'da kalabilmesi için kendisine 4500 lira vermiş olduğu iftirasıyla açığa alınmıştır. Ankara Ağır Ceza Mahkemesi'nce yapılan tahkikat neticesinde suçu sabit görülmeyerek 1 Haziran 1928'de tekrar hizmete alınmış, 14 Ekim 1928'de ise kendi isteğiyle emekliye ayrılmıştır. ${ }^{12}$

Resmî görevlerine ek olarak çeşitli cemiyet, dernek, encümen ve komisyon üyeliklerinde bulunmuş olan Efdaleddin Bey'in, üzerinde durulması gereken önemli faaliyetlerinden biri de Bâb-1 Âlî Kütüphanesi'ndeki evrakın tefrik ve tasnifi için 1916 'da oluşturulan Vesâik-i Târihiyye Tasnif Encümeni'nde Ali Emîri Bey ile birlikte yer almış olmasıdır. ${ }^{13}$

Efdaleddin Bey'in, emeklilik sonrasında da sosyal hayatındaki yoğunluk devam etmiştir. 1931'de İstanbul Zahire Borsası idare meclisi üyeliğine, 1936'da Türk Tarih Kurumu üyeliğine, 1940'da Türkiye İlmî Eserleri Koruma Derneği daimi üyeliğine seçilmiş, 27 Mayıs 1917'de kurulan ve Târîh-i Osmânî Encümeni’nin temsilcisi olarak katıldı ̆̆ İstanbul Muhâfaza-i Âsar-1 Atîka Encümeni (sonra İstanbul Eski Eserleri Koruma Encümeni)'nin de vefatına kadar en eski üyesi sıfatıyla başkanlığını yapmıştır. ${ }^{14}$

Efdaleddin Bey'in yukarıda kaydettiğimiz idarî görevlerinin yanı sıra yürüttüğü yoğun hocalık hayatını ise ayrıca ele almak gerekmektedir. İlk olarak 1896'da Aşîret Mektebi Sınıf-1 Mahsûs'u Ahlâk, Usûl-i İnşâ ve Kavâid dersleri öğretmenliğine atanmıştır. 1897'de Mekteb-i Sultânî̀ye Kitâbet-i Türkî, Mülkiye Mektebi İdâdi Kısmı'na Coğrafya-i Umrânî öğretmeni olarak; 1899'da Mercan İdâdisi Tarih öğretmenliğine; 1901'de Dârulfünûn Umûmî ve Osmanlı Tarihi öğretmenliğine atanmıştır. 1902'de yine ek görev olarak Mülkiye Mektebi Yüksek Kısım, Sınâî ve Ticârî Coğrafya ile İstatistik öğretmenliğine görevlendirilmiştir. 25 Aralık 1909'da Mülkiye Mektebi Siyasî Tarih ve Osmanlı Tarihi öğretmenliğine getirilmiş olan Efdaleddin Bey'e, 1911'de Kadastro Mektebi Tersîmât-1 Riyâziye, 1912'de Dârulfünûn Edebiyat Fakültesi Coğrafya, 1913'de Evkâf Mektebi İhtiyat Sınıfı Osmanlı Tarihi

12 Emekli Sandığı Arşivi, MO/115923 Numaralı Sicil Dosyası.; M. A. Çankaya, Mülkiye Tarihi ve Mülkiyeliler, III, 518.

13 Belgelerle Arşivcilik Tarihimiz (Osmanlı Dönemi), Devlet Arşivleri Gen. Md. Yay., Ankara, 2000, I, 77.

14 İslâm-Türk Ansiklopedisi Muhitülmaârif Mecmuast, 17 Nisan 1942, I, Nr: 32, s. 3-4; Celâl Esad Arseven, "Eski Eserleri Koruma Encümeni", Sanat Ansiklopedisi, İstanbul, 1950, I, 533-534; Semavi Eyice, "Tekiner, Mehmed Efdaleddin", Türk Ansiklopedisi, Ankara, 1982, XXXI, 41; "Tekiner, Efdaleddin", Dünden Bugüne İstanbul Ansiklopedisi, İstanbul, 1994, VII, 235; Fahri Çoker, Türk Tarih Kurumu, Kuruluş Amacı ve Çalışmaları, s. 501. 
öğretmenliği verilmiştir. Bunlara ilaveten 30 Eylül 1914'de kurulan İnas Kız- Dârulfünûnu Edebiyat Şubesi İslâm Tarihi, Coğrafya ve Lisân-1 Osmânî öğretmenliğine atanmıştır. İstanbul hükümetinin ilgasına kadar bu görevlerde kalmıştır. 14 Ekim 1928'de emekli olduktan sonra uzunca bir süre de Darüşşafaka'da tarih öğretmenliği yapmıștır. ${ }^{15}$

Otuz beş yıllık memuriyet ve otuz dokuz yıllık hocalık hayatını 13 Ağustos 1957'de İstanbul'da noktalamış olan Efdaleddin Bey'in, Emine Hanım (1882-1946)ile olan evliliğinden, Mehmed Haldun (1903-1965), Fatma Zehra (Sonel) (1905-?) ve Ayşe Adviye (Aytaç) (1907-?) isimlerinde üç çocuğu olmuştur. ${ }^{16}$

\section{KIŞILIĞi, ENTELEKTÜEL VE SOSYAL YÖNÜ}

Biyografik bir çalışmanın belki de en zor yanlarından birisi, hakkında araştırma yapılan kişinin şahsiyet ve karakterine ilişkin kısmın yazılmasıdır. Bu durum zaman zaman veri eksikliğinden kaynaklandığı gibi, çoğu zaman da o kişi hakkında yanlış bir kanaat ortaya koyma endişesinden kaynaklanır. Bunun için de yazar, mümkün mertebe onunla görüşmüş ve münasebette bulunmuş insanlara veya yazdıklarına müracaat etme ihtiyacı hisseder. Biz araştırmamızda Efdaleddin Bey'in ailesinden kimseye ulaşamadık. Ancak elimizde, Efdaleddin Bey ile yakın münasebeti olmuş dostlarının, onun vefatı üzerine kaleme aldıkları yazıları mevcuttur. Bu nedenle, eserlerindeki üslup ve ifadelerine dayanarak zihnimizde oluşan kanaatlere geçmeden önce, onu yakından tanıyan Tayyib Gökbilgin, Haluk Y. Şehsuvaroğlu ve Semavi Eyice'nin anlattıklarını dikkate almakta yarar vardır.

Efdaleddin Tekiner'in hayatı ve tarihçiliği üzerinde duran Tayyib Gökbilgin, ${ }^{17}$ onu Türk tarihçiliğinin büyük bir kaybı olarak gördüğünü ifade etmiştir. Efdaleddin Bey'in birçok meziyet ve iyi vasfın yanı sıra, tarih hocası, tarih araştırıcısı ve tarih yazarlığı gibi üç vasfı zatında toplamış olduğunu belirten Gökbilgin, onun tarihçiliği ve kişiliğine ilişkin önemli bilgiler de kaydetmiştir.

Buna göre, İstanbul'un tanınmış ve kültürlü bir ailesine mensup bulunan Efdaleddin Bey, daha genç yaşlarından itibaren tarih hocalığını kendisine

15 BOA, Sicill-i Ahvâl Defteri, Nr: 71, s. 83-84. Ayrıca bkz. İslâm-Türk Ansiklopedisi Muhitülmaârif Mecmuası, 17 Nisan 1942, I, Nr: 32, s. 4; Semavi Eyice, "Tekiner, Mehmed Efdaleddin", XXXI, 41; Fahri Çoker, Türk Tarih Kurumu, Kuruluş Amacı ve Çalışmaları, s. 501.

16 Emekli Sandığı Arşivi, MO/115923 Numaralı Sicil Dosyası.

17 M. Tayyip Gökbilgin (1907-1981), Osmanlı tarihçisi, 1943’te Türk Tarih Kurumun üyesi olmuştur. Hakkında geniş bilgi için bkz. Mübahat S. Kütükoğlu, "Gökbilgin, M. Tayyip", DİA, İstanbul 1996, XIV, 137-138. 
asıl meslek seçmiştir. Mülkiyede hukuk ve Galatasaray'da tarih tedrisatında bulunuşu onun kısa zamanda müdekkik bir tarih hocası olarak yetişmesine ve tanınmasına yardımcı olmuştur. Daha 30 yaşında iken Dârulfünûn'a Osmanlı Tarihi müderrisi olmuş (1317/1901), Birinci Dünya Harbi başlarına kadar bu vazifede bulunmuş, Abdurrahman Şeref Bey'in reisi bulunduğu Târîh-i Osmânî Encümeni’nde daimi üye olarak yer almıştır.

Gökbilgin, onun bu görevinden "Bugünkü Türk Tarih Kurumu'nun vazife ve faaliyet sahası itibariyle nüvesini teşkil eden encümenin şimdiye kadar, 12 daimi azasından hayatta kalmış kıdemli ve çok kıymetli tek ilim adamı idi" diye bahsetmiştir. ${ }^{18}$

Gökbilgin onun çalışma azmi ve merakını da överek, hayatının son zamanlarında Türk Tarih Kurumu'nun kendisine tevdî ettiği bir vazifeyi tamamlamak için çok acele ettiğinden, seksen yaşını hayli geçmiş olmasına rağmen bir öğrenci edası ve sadakatiyle haftalarca üniversite kütüphanesine devam ederek Silahdar Tarihi'nin basılmamış kısımlarını, muhtelif yazmalar üzerinde tetkik ve mukayese etmek suretiyle ve tenkidli bir şekilde neşre hazırlamış olduğundan bahsetmiştir. Ona göre Efdaleddin Bey, bu sıralarda adeta ölümün yaklaştığını bir önseziyle hissediyor ve milletine son büyük hizmetini tamamlayamamaktan korkuyordu. Kendisini son kez o y1lın bayram günü ziyaret ettiğini ve acil şifalar temenni ettiğini belirten Gökbilgin, o son görüşmelerinde üstadın oldukça hasta olmasına rağmen Tarih Kurumu'nun yeniçağ kolu faaliyetlerine sonbaharda tekrar katılmak arzusunda bulunduğunu söylemekten de kendisini alamadığını ifade etmiştir. Efdaleddin Bey’in, tamamlanacak eserleri bir vazife olarak gördügüüü, tarihçi şahsiyetinin de emsalsiz bir örnek olarak gelecek tarihçi nesillere miras halinde intikal ettiğine değinen Gökbilgin, onun manevî bir talebesi ve Türk Tarih Kurumu'nda on dört senelik bir arkadaşı sıfatıyla ebedî istirahatgâhında nur içinde yatmasını dilerken, "hatırasını ta'zîz ve tebcîl etmeği kutsî bir vazife biliriz" demiştir." 19

Vefatı üzerine Efdaleddin Bey ile ilgili düşüncelerini dile getirmiş olan bir diğer kişi de Haluk Y. Şehsuvaroğlu'dur. Şehsuvaroğlu, Efdaleddin Bey'in eski ricali, eski İstanbul'u pek iyi tanıyan, hafızaları kuvvetli, sohbetleri tatlı şahsiyetlerin sonuncusu olduğunu ifade etmiştir. Efdaleddin Tekiner'in uzun ömründe, en mühim yeri hocalık mesleğinin teşkil ettiğini belirten Şehsuvaroğlu, memur, muharrir ve tarihşinas olarak da bütün muhitlerde sevilen,

18 M.Tayyib Gökbilgin, "Kaybettiğimiz Değerler: Efdaleddin Tekiner", Türkiye Turing ve Otomobil Kurumu Belleteni, S. 188, Eylül 1957, s. 3.

19 M.Tayyib Gökbilgin, "Kaybettiğimiz Değerler: Efdaleddin Tekiner", s. 3-4. 
hürmet edilen bir şahsiyet olduğuna dikkat çekmiş, etrafındakilere olan muamelesi, nezaketi, kibarlığı ile onu gerçek bir İstanbul beyefendisi olarak tavsif etmiştir. ${ }^{20}$

Efdaleddin Tekiner'in tedris hayatı ve çok derin bilgisine nazaran neşriyatının azlığının ileri sürüldüğüne dikkat çeken Şehsuvaroğlu, onun, şarktaki bazı ilim adamlarının yolunda yürümüş olduğunu, yazmaktan ziyade anlatmayı ve kendisine müracaat edenleri aydınlatmaktan geri kalmamış olduğunu belirtmiştir. Kendisinin de zaman zaman katıldığ eski Bâbıâlî mensuplarına âşina olduklarından, bazı ma'zul vezirlerin hikayelerini dinleyerek o devirlerin devlet adamları ve uleması hakkında bilgiler edindiklerinden bahsetmiştir. ${ }^{21}$

Efdaleddin Tekiner'in, kuruluşundan itibaren intisap ettiği Eski Eserleri Koruma Encümeni'nde, hayatının sonuna kadar vazife gördüğünü ve bu cemiyetin başkanı olarak vefat etttiğini belirten Şehsuvaroğlu, onun uzun ömrü içinde bu hizmetin büyük ve mühim bir yeri olduğuna dikkat çekmiştir. Çünkü ona göre Efdaleddin Bey, İstanbul'u geçmiş zamanlarıyla ve bugünü ile bilen, bütün âbideleri teferruatıyla tanıyan, mevcud olmayan eserlerin yerlerini, mimarî tarzlarını, gördükleri hizmetleri söyleyen, eski konakları, yalıları, inşâ tarihleriyle, sahipleriyle birer birer anlatabilen, hayatta kalmış yegane İstanbullu idi. ${ }^{22}$

Nitekim geçmişte Kapalıçarşı'da çıkmış olan yangınları konu edinen bir yazıda, Efdaleddin Bey'in eserleri kısmında kaydettiğimiz bir yazısı, kültürle ticaretin iç içe girdiği böylesine güzide bir merkeze ait yapılan nadir çalışmalardan biri olarak okurlara hatırlatılmıştır. ${ }^{23}$

Şehsuvaroğlu, Efdaleddin Bey'in babadan kalma bir eski zaman konağında, eski zaman eşyası arasında oturduğunu, sevimli yüzünü çevreleyen bütün bu hatıraların, onu olduğundan daha eski zamanlara aitmiş gibi gösterdiğini ifade etmiştir. Son olarak "Gördüğü, bildiği, yaşadığı zamanların hikâyeleri henüz tükenmeden, hele asla yazılmadan seksen yedi yıllık baş1nın bir daha kalkmamak üzere yastığa düşmesi, dostları, yakınları ve tarih için ne kadar acı oldu" diyerek vefatından duyduğu derin üzüntüyü dile getirmiştir. ${ }^{24}$

20 Haluk Y. Şehsuvaroğlu, "Merhum Efdaleddin Tekiner", Türkiye Turing ve Otomobil Kurumu Belleteni, S. 189, Ekim 1957, s. 5.

21 H. Y. Şehsuvaroğlu, "Merhum Efdaleddin Tekiner", s. 5.

22 H. Y. Şehsuvaroğlu, "Merhum Efdaleddin Tekiner", s. 5.

23 Bkz. Kapalıçarşı Dergisi, S. 2. (http://www.kapalicarsi.com/2tr/konular/yangin.htm. 24.01.2004)

24 Haluk Y. Şehsuvaroğlu, "Merhum Efdaleddin Tekiner", s. 5. 
Semavi Eyice de, ${ }^{25}$ kendisiyle bir süre beraber olmuş biri olarak, Efdaleddin Bey'in gerçek anlamda bir "Bey" ve son İstanbul efendilerinden olduğunu, konuşma üslubu, davranışları ve bilhassa giyinişi ile bunu açıkça belli ettiğini ifade etmiştir. Ancak onu, İstanbul'u yakın tarihi, yapıları ve insanlarına dair engin bilgiye sahip olmasına rağmen, Kapalıçarşı'ya dair bir yazısı dışında bu konuda hemen hemen yazılı hiçbir ürün vermemekle eleştirmiştir. $^{26}$

Bizim de çalışmalarından edindiğimiz intibaya göre onun, öncelikle dinî ve millî hissiyatı son derece güçlü, vatansever, çalışkan bir Osmanlı aydını olduğunu ifade etmemiz gerekir. Efdaleddin Bey'in kişiliğine ilişkin en önemli bulguları, hocası Abdurrahman Şeref Bey hakkında kaleme almış olduğu eserden elde etmekteyiz. Eserde hocasını anlatış tarzından, onun ilme ve ilim adamına son derece hürmetkâr ve vefakâr olduğu; muavini olması nedeniyle de derslerini sürekli takip etmekle hocasını ciddi anlamda örnek almış olduğu rahatlıkla söylenebilir. Hocasının derslerdeki hitap tarzı, konulara giriş ve ele alış tarzı, kendisinde hocalık mesleğini sevmeye etki eden en önemli unsurlardandır. Bahsettiği üzere hocasının her yıl aynı dersin aynı konularında kullandığı hatıra ve hikâyeleri, muhtemelen kendisi de kullanmıştır. Nitekim yukarıda kendisi ile görüşmüş biri olarak kaydettiğimiz Gökbilgin'e ait cümleler, bu tespitlerimizi doğrulamaktadır.

Türkiye Turing ve Otomobil Kurumu da, otuz beş yıl kadar İstanbul Türk abideleri ve sosyal tarihi hususlarında tükenmez ve sınırsız malumatından daima istifade ettikleri Efdaleddin Bey'in vefatının, gerek memleket gerekse kurumları için yeri doldurulmaz bir kayıp olduğunu belirterek, yukarıda onunla ilgili görüşlerini aktardığımız üç kıymetli tarihçinin mütalaalarını bir kitapçık halinde neşretmiştir. ${ }^{27}$

Efdaleddin Bey, Mülkiye Tarihi ve Mülkiyeliler adlı eser için kaleme aldığı kısa otobiyografisinde de, gençliğinde kaleme aldığı birkaç tiyatro eseri ve Mektep mecmuasında basılmış şiirleri olduğundan bahsetmiştir. Buna göre kendisinin edebiyat ve çeşitli sanat dallarına oldukça ilgili olduğunu belirtmek mümkündür. ${ }^{28}$

25 1923'de İstanbul'da doğan Semavi Eyice, Bizans ve Osmanlı sanatı tarihçisidir. Geniş bilgi için bkz. Ekrem Işın, "Eyice, Semavi", Dünden Bugüne İstanbul Ansiklopedisi, İstanbul, 1994, III, 236-237.

26 Bkz. Semavi Eyice, "Tekiner, Mehmed Efdaleddin”, Türk Ansiklopedisi, XXXI, 41; "Tekiner, Efdaleddin", Dünden Bugüne İstanbul Ansiklopedisi, VII, 235-236.

27 Üstad Efdaleddin Tekiner, Türkiye Turing ve Otomobil Kurumu Yay., İstanbul, 1958.

28 M. A. Çankaya, Mülkiye Tarihi ve Mülkiyeliler, II, 260. 
Bir örnek olması bakımından, Efdaleddin Bey'in, 16 Mart 1942 tarihi itibariyle Türk basınındaki ilk yazılarının üzerinden 50 yıl geçmiş olanlar için yapılan jübilede (6 Şubat 1943), kendisine uzatılan mikrofona söylediği şu şiirini kaydedebiliriz:

Genç çağdayım: Kendimi bir dikenli yolda buldum, Hıçkırıklar işittim, gül ve bülbül bağlarından, Felâketler topladım, Anadolu dağlarından, Uzun sazlı âşılar diyarında şâir oldum.

Ezgi koydum: Âhlarla figanlarla Türk şiirine, Öz dilimle haykurdım: "Ey milletim, uyan diye, Viran yurdun dolaştım, bir şehrinden bir şehrine, Saç ve sakal ağarttım ben de: "Vatan vatan!" diye. ${ }^{29}$

Bu jübileye katılan 59 kişiden biri olması da, Efdaleddin Bey'in entelektüel çevredeki etkinliği ve saygınlığına işaret etmektedir. Hayatı kısmında daha çok kronolojik olarak vermeye çalıştığımız bilgileri gözden geçirdiğimizde, Efdaleddin Bey'in resmî görevleri yanı sıra birçok okulda dersler vermesi, birçok kurum ve komisyonda üyelik, başkanlık görevlerinde bulunmas1, onun, çevresinde ne derece etkin, sosyal ilişkileri ne kadar kuvvetli bir kişiliğe sahip olduğunu anlamamıza yardımcı olmaktadır.

\section{ESERLERI}

\section{A. Kitapları}

1. Coğrafya-i Umrânî, Mahmud Bey Matb., İstanbul 1316/1898, $x X+370 s$.

Tarihin yararlandığı ilim dallarının başında gelen coğrafyanın, o dönemde Osmanlı ülkesinde yeni yeni tanınan Beşerî Coğrafya koluna ilişkin bir eserdir. Tespit edebildiğimiz kadarıyla Efdaleddin Bey'in yayınlanan ilk kitabıdır. Maârif Nezareti'nin 1314/1896 tarihli ruhsatıyla basılmıştır. Buna göre, Efdaleddin Bey'in henüz öğretmenliğe başlamadan, daha Âmedî-i Dîvân-1 Hümâyûn halifeliğinde görevli iken bu eseri kaleme almış olduğu anlaşılmaktadır.

Efdaleddin Bey, Coğrafya-i Umrânî dersi Osmanlı eğitim-öğretim sisteminde yeni bir ders olduğu için, eserinin başında yirmi sayfa kadar bu dersin içeriği ve önemi ile ilgili açıklamalarda bulunmuştur. Burada kaydettik- 
lerine göre Coğrafya-i Umrânî, başlangıçta Tabiî ve Politikî Coğrafya ile beraber ele alınmaktaydı. Bir hayli zamandan beri Avrupa'da tanınmış olan bu fennin önemi, Osmanlı devletinde de takdir edilmeye başlanmış ve ayrı bir bilim dalı şekline girmiştir. Bu ders ilk olarak Alman doğubilimci Andreas David Mordtmann ${ }^{30}$ tarafından Mülkiye Mektebi'nde okutulmaya başlanmıştır. Hüseyin Paşa'nın yalnız Osmanlı Devleti için yazdığı Coğrafya-i Zirâ̂̃ adlı kitap da bu sıralarda yazılmış ve çok faydalanılan bir eser olmuştur. Bundan sonra asıl umrânî olmak üzere zirâî, sınâî, ticarî kısımları ihtiva eden bir kaç eser yazılmıştır. Ancak "Coğrafya-i Umrânî" adını taşıyan ve Osmanlı devleti dışındaki memleketlerin de beşerî coğrafyasını sunan ilk eser Abdurrahman Şeref Bey'e aittir."31

Bu açılamalar doğrultusunda bügünkü anlamıla "beşerî coğrafya" olan coğrafya-i umrânînin, Efdaleddin Bey'in o dönemde oldukça yakından ilgilendiği bir alan olduğu anlaşılmaktadır. İlgisinde Mülkiye Mektebi'ndeki öğrencilik yıllarında ve daha sonra da büyük oranda Abdurrahman Şeref Efendi'nin etkili olduğu kuvvetle muhtemeldir.

Çünkü Efdaleddin Bey, hocası Abdurrahman Şerefin bu ilim dalına katkıları üzerinde önemle durmuştur. Her bilim dalınının kendine ait bir terminolojisi olduğunu belirten Efdaleddin Bey, Abdurrahman Şeref Bey'in eseri neşredilinceye kadar Osmanlı memleketinde beşerî coğrafyaya dair tek bir ıstılahın bile mevcut olmadığını dile getirmiştir. Bu bilim dalının terminolojisini Fransızca asıllarının müradiflerini oluşturarak vücuda getirmiş olan Abdurrahman Şeref in, böylece yıllardır binlerce öğrencinin yetişmesine hizmet etmiş olduğuna dikkat çeken Efdaleddin Bey, aynı alanda daha sonra yazılan eserlerin tamamının onun eserinden yararlanılarak yazıldıklarını, dolayısıyla Osmanlı memleketinde bu ilim dalında ilk olma özelliğinin ona ait olduğunu belirtmiştir. ${ }^{32}$

Efdaleddin Bey, Abdurrahman Şerefin muhtemel etkisine ek olarak bu eseri yazmaya, ismini vermediği muhterem bir hocasının teşvik ettiğinden

30 Andreas David Mordtmann (1811-1879) Alman doğubilimcidir. Hamburg Şehir Kütüphanesi'ndeki Doğu yazmalarının kataloğunu hazırlamıştır. Batı dilleri yanı sıra Arapçasının mükemmel olduğu bilinmektedir. Kendisine 1845 yılında Kiel Üniveristesi Felsefe Fakültesi'nce “Doktor" payesi verilmiştir. 1860'da İstanbul'a yerleşmiş, o sıralarda yeni kurulan Ticaret Mahkemesi'nde on yıl hâkim olarak görev yapmıştır. 27 Kasım 1871'de Sadrazam Mahmud Nedim Paşa tarafından görevden alınmıştır. 1877’de Mekteb-i Mülkiye'nin öğretim üyeliğini kabul ederek burada Coğrafya ve İstatistik derslerini üstlenmiştir. 1879'da İstanbul'da ölmüştür. Bkz. Semavi Eyice, "Mordtmann, Andreas David", Dünden Bugüne İstanbul Ansiklopedisi, İstanbul, 1994, V, 489-490.

31 Bkz. İbnü'l-Cevâd Efdaleddin, Coğrafya-i Umrânî, Mahmud Bey Matbaası, İstanbul, 1316/ 1898, s. $14-15$.

32 Bkz. Efdaleddin, Coğrafya-i Umrânî, s. 15-17. 
bahsetmiştir. Hocası Abdurrahman Şeref in derslerinde tutmuş olduğu notların, kendine bu kitabı yazabilme cesareti verdiğinden bahsetmiş, dolayısıyla eserin manen hocası Abdurrahman Şerefe ait olduğunu belirtmiştir. Osmanlı devletinde yeni bir fen olduğu için, kitapta yeni ve alternatif bir düzen yakalanmaya çalışıldığını belirten Efdaleddin Bey, bu bilim dalının konusunu ise "insanlığın refahını teşkil eden medeniyeti meydana getiren ve bütün hayatî ihtiyacları karşılayan zirâat, sanâi ve ticâret adı altındaki üç temel yükselme unsurunun şekli" olarak ifade etmiştir. ${ }^{33}$

Dört bölüm olarak düşünülmüş olan eserin, malî kanunlar ve istatistikî bilgileri içerecek olan dördüncü bölümü henüz mekteplerdeki Coğrafya-i Umrânî ders programına girdirilmediğinden bu kitabta yer verilmekten vazgeçilmiştir. Eser iki cilt olarak düşünüldüğü için bahsi geçen konulara o ciltte yer verilmesi tasarlanmış, ancak daha sonra bu düşünce gerçekleşmemiştir. Bize ulaşan şekliyle eserin bölümleri ise şu şekildedir:

\section{Mukaddime}

Medhal

Birinci Bölüm: Mâlumât-ı İbtidâiyye (Ziraat, sanayi ve ticarete ilişkin terminoloji) s. 6-118.

İkinci Bölüm: Memâlik-i Osmaniye (Ziraat, Sanayi ve Ticaret) s. 119290.

Üçüncü Bölüm: Memâlik-i Ecnebiye (Amerika, İngiltere, Almanya, Avusturya, Macaristan, Italya, Rusya, Fransa, Balkan memleketleri) s. 291-363. Efdaleddin Bey, bu kısmı Abdurrahman Şeref Bey'in eserinden ${ }^{34}$ özetleyerek iktibas ettiğini belirtmiştir.

2. Muhtasar İslâm Tarihi, I. Cilt, Kader Matb., İstanbul 1326/1908, $455 \mathrm{~s}$.

Kitabın iç kapağındaki 1. cild ve 1. kısım ifadelerinden, kitabın aslında daha hacimli bir çalışma olarak düşünüldüğü anlaşılmaktadır. ${ }^{35}$

Birinci Kısım'ın içeriği ile ilgili açıklamaya göre ise bu kısım, Emevî Devleti'nin sonuna kadar olan İslâm tarihini içermektedir. Anlaşılan o ki Efdaleddin Bey, bu eserinin ciddi bir planını çıkarmış, kapsayacağı tarihleri belirlemiş, ancak yalnızca 132/749 tarihine kadar olan İslâm tarihini yazabil-

33 Bkz. Efdaleddin, Coğrafya-i Umrânî, s. 12, 16-18.

34 Abdurrahman Şeref, İstatistik ve Coğrafya-i Umrânî, Karabet Matbaası, İstanbul, 1314/1896.

35 Çünkü iç kapaktaki ifadeye göre eserin birinci cildi, hicri 700/1300'e kadar olan kısmı kapsamaktadır ve bu ciltte sadece birinci kısım bulunmaktadır. 
miştir. Muhtemelen elinde bu çalışma ile ilgili ciddi bir malzeme ve müsvedde kalmıştır, ancak daha sonra neden tamamlayamadığ ile ilgili herhangi bir açıklamasına rastlayamadık.

Efdaleddin Bey'in eseri kaleme alış gerekçesi ve amacıyla ilgili sözleri şu şekildedir:

"ifade:

Şimdiye kadar târîh-i İslâm’a dair pek çok eserler vücuda getirilmiş̧ir. Bunların her biri, nev'i arasında kıymetdar parçalar olmakla beraber ilk mâlûmât-ı târîhiyye alacak fikirler için ya gâyet mufassal veya lüzûmundan ziyâde muhtasardır. Vekâyi-i târihiyye arasında pek mühim safahâtı hâvî olan târîh-i İslâm cildler teşkîl edecek derecede vâsı' olmakla beraber sıra ve ehemmiyet itibâriyle lüzûmu kadar tafsîlli olarak mutâlaa olunmak için bu eserde tatbik edilen usûl kifâyet eder zannındayım.

Maksad; tetebbuât-1 ciddiye arzu edenlere bir fihristden edecekleri istifâdeyi te'mîn edebilmek, mücmel ve esaslı mâlûmat edinmek isteyenlere de vus' derecesinde hizmet eylemekdir.

Târih derslerine başlayan talebenin de ihtiyacına kifâyet edecek olan şu kitap, kendi nev'i itibariyle bir ders kitabı dahî olabilir.

Bu nâçiz eserle ümîd edilen şu fevâid husûle gelirse arzu olunan hizmet maksadı te'mîn edilmiş olur ki bu da müellif-i âciz için bâis-i şükrândir.

Ve minellahi't-tevfîk."36

Efdaleddin Bey eserde, olayları daha çok İslâm öncesi ve sonrasını karş1laştırarak anlatmış, olayların dinî boyutlarına girmemiş, tartışmalardan uzak durmuştur. Yapmış olduğu değerlendirmelerde Arap toplumunun siyasi ve sosyo-kültürel yapısını göz ardı etmemiştir. Özellikle İslâm tarihinde Hz. Osman'dan sonra ortaya çıkan ihtilaflar, bunların artarak devam eden olumsuz etkileri, daha çok kitapta oldukça ciddi bir yer tutan Emevî hanedanı ile ilişkilendirilerek anlatılmıştır. Sürekli olarak İslâm'dan önce var olan EmevîHâşimî mücadelesi ile bağ kurulmuştur. Emevîler döneminde her ne kadar fetihlerde, ilim, sanat ve kültürel faaliyetlerde birtakım ilerlemeler kaydedilmiş olduğundan bahsetmişse de, bu kısımdaki anlatımlarında Efdaleddin Bey'in esasında Emevîler'i İslâm'ın çok daha hızlı ve geniş bir sahada yayılmasında engel olarak gördüğü anlaşılmaktadır. Bu kısımdaki anlatımı Efdaleddin Bey'in dinî hassasiyetini yansitan ifadelerle doludur. Ömer b. Abdülazizi'i istisna etmesinin dışında hemen bütün Emevî yöneticilerini ehl-i beyt 
düşmanı olarak görmüş, bir yerde Muâviye için "hilekâr"37 ; I. Yezid için "kara vicdanlı, zalim" 38 ; II. Velid için "fâsık, mücrim ve alçak tabiatlı; dinsiz, sarhoş ve 1rz düşmanı" 39 ; Haccac için "dinsiz ve dünyada benzeri ancak bir iki tane olabilecek bir zalim"40 ifadelerini kullanmıştır. Bu açıdan bakıldığında bir tarih yazarı olarak Efdaleddin Bey'in hissiyatını gizleyemediğini belirtmek gerekmektedir.

Ancak Efdaleddin Bey'in, olayları neden-sonuç ilişkisi kurarak anlatmaya özen göstermesi; başta halifeler, valiler ve komutanlar olmak üzere olayların kahramanlarını genel olarak hem fizikî hem de psikolojik yapılarıyla tanıtmaya çalışması, onun sıradan bir tarihçi olmadığına işaret etmektedir. Bu yönüyle yazar, okuyuculara söz konusu kişilerin yetişme şartlarını, İslâm toplumu içerisindeki fonksiyonlarını ve diğer önde gelen şahsiyetlerle ilişkilerini sağlıklı bir şekilde takip ve tahlil etme imkânı vermiştir.

Efdaleddin Bey'in metin içerisine yerleştirdiği harita ve şemalarla, görsel malzeme kullanmaya özen gösterdiği de görülmektedir. Kitapta Hz.Peygamber'in, Emevî ve Abbasî ailelerinin neseplerini gösterir üç şema ${ }^{41}$ ve müslümanların siyasî hâkimiyet kurdukları coğrafyayı gösteren üç harita bulunmaktadır. Coğrafyaya yakın ilgisini bildiğimiz yazarın -haritalar üzerinde eserin isminin yazılmış olduğuna bakılırsa- kitaptaki haritaları bizzat kendisinin hazırlamış olabileceğini söylemek mümkündür.

Eserde dipnot uygulaması oldukça zayıftır. Yazar bu uygulamayı alıntı yaptığı eserlere işaret etmek yerine daha çok bazı terimleri açıklamak için kullanmıştır. Pek çok yerde de fazla ayrıntıya girmemek için "tafsîlâtı tevârîhde zikrolunur" ifadesinin yer almasına bakılırsa, Efdaleddin Bey'in, esasında eserini zengin bir birikime sahip olarak yazmış olduğu rahatlıkla anlaşılmaktadır. Ancak bazı alıntıları nereden yaptığına ilişkin açıklamayı sadece bir kaç yerde yapmıştır. ${ }^{42}$ Bunların da kiminin yazar kiminin ise eser ismini yazmıştır:

-Corci Zeydan, Târîhu’t-Temeddüni'l-i̇slâmî,

-Mes'ûdî, (Muhtemelen Murûcü'z-Zeheb),

-Abdurrahman Şeref in Zübdetü'l-Kısas'1,

-Endülüs Tarihi, (Muhtemelen Halef b. Hayyân el-Kurtubî (987-1076)'nin el-Muktebes fí Târîhi'l-Endelüs adlı eseri),

37 Efdaleddin, Muhtasar İslâm Tarihi, s. 208.

38 Efdaleddin, Muhtasar İslâm Tarihi, s. 218, 220.

39 Efdaleddin, Muhtasar İslâm Tarihi, s. 298.

40 Efdaleddin, Muhtasar İslâm Tarihi, s. 250.

41 Efdaleddin, Muhtasar İslâm Tarihi, s. 40, 196, 363.

42 Bkz. Efdaleddin, Muhtasar İslâm Tarihi, s. 192, 211, 217, 219, 226, 262, 284, 326, 370, 373 , 381, 392, 396, 402, 410, 412 
-Mir'âtü'l-İber, (Muhtemelen Diyarbakırlı Said Paşa'nın genel tarihi), -Müneccimbaşı'nın Sahâifu'l-Ahbâr'',

-Emir Ali (Muhtemelen Hintli alim Seyyid Emir Ali (1849-1928)'yi kastediyor ve eseri The Spirit of Islam'a atıfta bulunuyor)

Efdaleddin Bey'in bunlardan en fazla hocası Abdurrahman Şeref ve Corci Zeydan'ın eserlerinden yararlandığı anlaşılmaktadır.

Eser daha çok halka ve tarih derslerine yeni başlayanlara yönelik olarak hazırlandığı için sade bir anlatıma sahiptir. Ancak aktardığı bilgiler bakımından oldukça doyurucu, değerlendirmeleriyle ufuk açıcı niteliktedir. Bu açıdan Efdaleddin Bey'in, eseri hakkında isminde kullandığı "muhtasar" ve mukaddimesindeki "bir fihrist ya da ders kitabı" nitelemelerini tevazu olarak kabul etmek gerekir.

Konuları titiz bir şekilde planlamış olan Efdaleddin Bey'in bu eseri, 1914'deki medreselerin ıslahı çalışmaları esnasında, ders kitabı olarak okutulacak eserler listesinde yer almıştır. ${ }^{43}$

3. Küçük Osmanlı Tarihi, Karabet Matb., İstanbul 1328/1910, 197+2 s.

Kitabın iç kapağındaki "Maârif nezâretinin kabul ettiği resmî programa göre rüşdî ve idâdî mekteplerinin ikinci sınıflarında okutulmak üzere tertib olunmuştur" ibaresine göre ders kitabı olarak hazırlanmış olduğu anlaşılmaktadır. Efdaleddin Bey'in bu eserde daha didaktik bir tavır sergilediği de zaten eserin girişindeki tarihin anlam, yarar ve amacına ilişkin ifadelerinden açıkça anlaşılmaktadır. Tarihini bilmeyen bir milletin, babasını bilmeyen insanlar gibi olduklarını belirten Efdaleddin Bey, 600 senelik şanlı ve şerefli bir maziye sahip olarak yeni yetişen nesilden ecdadına layık olmalarını istemiştir. Ancak, bütün başarılara rağmen onların zaman zaman hatalara düştüklerini de dile getirerek, öğrencilerinin bunlardan ders çıkarmaları gerektiğini öğütlemiştir. ${ }^{44}$

Efdaleddin Bey, bu eserde Osmanlı tarihini on devire ayırarak işlemiştir: ${ }^{45}$

43 Bkz. Zeki Salih Zengin, II. Meşrutiyet'te Medreseler ve Din Eğitimi, Ankara, 2002, s. 139.

44 Efdaleddin, Küçük Osmanlı Tarihi, s. 2-3.

45 Tanzimat dönemine kadar yazılmış olan tarih kitaplarında genel olarak her bir padişahın dönemi kronolojik sıra ile yazılmıştır. Ancak zamanla, özellikle İbn Haldun'un devletlerin hayatına ilişkin sergilediği organizmacı yaklaşımdan etkilenilerek Osmanlı tarihinin devirlere ayrılarak yazılması usulü benimsenmiştir. Bu usul, daha çok ders kitabı olarak hazırlanan eserlerde, öğrencilerin kolay anlamalarını temin için tercih edilmiş bir yöntem olmuştur. Cumhuriyet dönemindeki pek çok eserde de bu metot takip edilmiştir. İlk olarak Ahmed Vefik Paşa (ö.1891)' nın, ders kitabı olarak hazırladı̆̆ı Fezleke-i Târîh-i Osmânî adlı eserinde uygulanmıștır. Aynı dönemde Mustafa Nuri Paşa (ö.1890) Netâyicu'l-Vukûât'ında, daha sonra da Abdurrahman Şeref Efendi (ö.1925) Târîh-i Devlet-i Osmâniyye'sinde bu usulü benimsemiştir. Onların altı ve yedi devirde ele aldıkları Osmanlı tarihini, Efdaleddin Bey ise daha ayrıntılı bir şekilde değerlendirerek on devire ayırmıştır. 
1. Te'sîs Devri (Devr-i Zehebî = Altın Devir) : : 1299-1388

2. Tezelzül (Sarsılma) Devri : $1388-1413$

3. Te'yîd (Toparlanma) Devri : :1413-1512

4. İkbâl (Saadet) Devri : 1512-1544

5. Tevakkuf (Duraklama) Devri : :1544-1616

6. Teşettüt (Çözülme) Devri : :1616-1682

7. İnhitat (Yıkılış) Devri : :1682-1703

8. İntibah (Uyanma) Devri : 1703-1791

9. Teceddüd (Yeniden yapılanma) Devri : : 1791-1839

10.Yeni Osmanlıcilık Devri : :1839-1876

Yazar, eserini "taht-ı Osmânîye el-yevm pâdişahımı şevketlu Sultan Mehmed Hân-ı Hâmis Hazretleri câlis oldular, 1327" ifadesiyle bitirmiştir. Olayların tarih sayılabilmesi için üzerinden en az yarım asır geçmesi gerektiğini ${ }^{46}$ belirten Efdaleddin Bey, 1876'dan 1327/1909'a kadar olan tarihi ise malumat kabilinden oldukça kısaca bir şekilde kaydetmiştir.

Osmanlı tarihinin her bir devrinin karakteristik özelliklerini padişahların icraatlarıyla bağlantılı olarak anlatan Efdaleddin Bey, tarihte sürekliliği ve neden-sonuç ilişkisini asla göz ardı etmeyerek dönemler arasındaki etkileşimi açıklamıştır. Eserdeki devirlere ayırarak anlatma üslubu, Cumhuriyet döneminde yazılan Osmanlı tarihlerinde takip edilen usulün o zamanlara dayandığını gösteren önemli bir örnektir.

Efdaleddin Bey'in üslubunda dikkati çeken en önemli husus, her bir devirden sonra, "fezleke" başlığı altında kişisel değerlendirmelerine yer vermesidir. Bu kısımlardan derlediğimiz kanaatlerini özetleyerek ve kısmen sadeleştirerek şu şekilde sıralayabiliriz:

1. Fezleke: İnsanlar yaratılıştan pek çok faziletlere sahiptirler, ancak bunlar birçok nedenle değişirler ve bozulurlar. Milletlerin böyle saf ve âl-i cenâb oldukları zamanlara, o milletin altın devri denilir. Osmanlı devletinin de altın devri Murat Hüdâvendigâr'ın vefatına kadar (791/1388) geçen zamandır. Illk üç padişah emsali bulunmaz kişilerdi. Gayretli, çalışkan, merhametli, dindarlardı. Tebaalarından kendilerini ayırmazlardı. Harb meydanlarında normal bir asker gibi savaşırlardı. Yönetim işlerinde istişareye önem verirlerdi. Adalet, ilim ve sanata değer vererek yükselmişlerdi. Yağmacılıktan yetişmiş göçebe bir halk değiliz. İktidarın gerekliliklerine vakıf büyük bir milletiz. ${ }^{47}$ 
2. Fezleke: Yıldırım Bayezid'le fetihler artarak devam etmiştir. Ancak fethedilen yerleri gerçekten zabtetmek ve buralarda kendini sevdirmek adaletle mümkündür. Bunun için hızla yapılan fetihlerde, iyi düşünülerek yapılanlara göre metanet yoktur. Kuruluş devrindeki fetihlerde fethedilecek yerlerdeki ahalinin geleceğine ilişkin bütün düzenlemeler önceden kararlaşt1rılırdı. Yıldırım Bayezid devrindeki fetihlerde ise bu durum görülmez. Bu nedenle, zabtolunan yerler Timurlenk bozgunundan sonra bir bir elimizden çıkmıştır. Ayrıca bu devirde memleket büyüdüğünden milletin servet ve refahı artmış, başta devlet erkânı olmak üzere millet israf ve sefâhet hastalı̆̆1na tutulmuştur. Fethedilen yerlerdeki milletlerin ahlâk ve âdetleri aramıza girdiğinden, ilk devrimizdeki temiz ve saf ahlâkımız yavaş yavaş bozulmuştur. Rum kadınlarla yapılan evlilikler de bunu körüklemiştir. Timurlenk Ankara'da ordumuzu mağlub edip devleti perişan edince kusurlarımız meydana çıkmıştır. Aslında bu mağlubiyet devlete çok faydalı olmuştur. Bu hal, kanı bozulan hastadan iyileştirmek için kan almaya benzer. Böyle olmasaydı Yıldırım Bayezid'in veliaht tayin etmiş olduğu sefih ve sarhoş bir adam olan Emir Süleyman padişah olacaktı. Oysa Ankara savaşı sonrasında şehzadeler arasında ortaya çıkan karışıklıklar içinden, emsali bulunmaz bir kişi olan Mehmed Çelebi padişah olmuştur. Neticede Ankara mağlubiyeti Osmanlı devleti için büyük bir nimet olmuştur denilebilir.

3. Fezleke: Bu devirde medeniyetimiz yükselme göstermiştir. Edebiyat, mimari ve harb tekniklerinde çok ilerlemiştik. Özellikle Fatih Hazretleri zamanında her alanda ilerlemiştik. Ancak "Mağlup olan milletler galib olan kavimlere kendi eski ve fena adetlerini vererek onları mutazarrır ederler (zarar verirler)" kaidesine göre biz de mağlup ettiğimiz milletlerden, özellikle Bizans Rumlarından sefahete ve hayat tarzlarına ait bazı adetleri alarak salâbetimizi ihlâl ettik. Dolayısıyla İstanbul'un fethinden sonra Rumlardan gördüğümüz pek çok şeylere alışıp bozulduk. Kanaatkâr iken şehirliler gibi müsrif olduk. Millî özelliklerimiz bu Te'yîd devrinde Orta Asya'daki aşiret yaşantımızdan uzaklaşarak şehirliliğin gayr-i saf olan yaşantılarına dönüştü. ${ }^{48}$

4. Fezleke: İkbal devri, Osmanlıların şandan şana, zaferden zafere geçtikleri zamandır. Sultan Selim'in bunda büyük katkısı olmuştur. Sultan Süleyman'ın ilk zamanları da onun bıraktığı maddî güçle parlak olmuştur. Kendisi her zaman israftan uzak durmuş olan Sultan Selim, oğlu Süleyman'ın süslü giyiniş ve hayat tarzını eleştirirdi. Serveti bol bulmuş olan Süleyman, bunu çok da iyi kullanamamıştır. Ancak her şeye rağmen bu 
devirde ilim ve fende fevkalâde ilerleme olmuştur. İran'dan getirilen ustalarla çinicilik, halıcılık ve mimari çok çok gelişmiştir. Fakat ilişki içerisine girdiğimiz Macarlar ve Akdeniz havzasındaki diğer milletlerden etkilenmeye devam ettiğimizden, önceki devirlere göre safiyetimiz daha da bozuldu ki bu durum inhitatımızı hızlandırmıștır. ${ }^{49}$

5. Fezleke: Tevakkuf (Duraklama) devri, Rüstem Paşa'nın sadrazamlığa gelmesiyle başlar. Bu nedenle bu devreye Sultan Süleyman'ın ikinci dönemi denir. Rüstem Paşa rüşvet ve suistimallerle devletin manevî gücünü bozmuştur. Görünürde fetihler ve icraatlar devam etmiş, devlet eski şan ve azametinde görülmüştür. Ancak tevakkuf devrinin özelliği zaten görünüşte parlak, ama gerçekte durgun olmasıdır. Çünkü bu devirde eski güce güvenilmiş, hazır servet yenmiş, harcananın yerine yenisi konmamıştır. Servet ve ihtişam aşırı yayılmış olduğundan zevk ve sefahet artmış, padişahlar bile sefahetten baş kaldıramaz olmuşlardır. Bir milletin sefahete dalması ise o milleti yok oluşa doğru sürükleyen bir haldir. ${ }^{50}$

6. Fezleke: Çözülme devrindeki padişahların bir kısmının devlet idaresinden aciz olmaları işleri daha çıkılmaz hale getirmiş, daha sonra iyi bir padişah gelse bile ancak öncekinin bozduklarını düzeltmekle uğraşmak durumunda kalmıştır. Nitekim Sultan IV. Murad ile Köprülüler bu devrin bozukluklarını temizlemişlerdir. Bunlar da olmasa devletin hali çok kötü olurdu.Kaldı ki, onların bu meşguliyeti dahi ülkede ticaret, ziraat ve sanayinin yüz üstü bırakılmasına sebep olmuştur. ${ }^{51}$

7. Fezleke: Eski güçlü, ihtişamlı zamanlarımızla övüne övüne bu hale geldik,devlet ıslahata muhtaçken gücümüzün üstünde işlere kalkıştık. Geleceği düşünmemek ve gerçeği görmemek hastalığ sonunda bizi uçurumun kenarına getirdi. Bu felâketlerin hepsi milletin eski fedakâr adamlardan mürekkep olmamasından ve devlet erkânının iktidarsızlığından ileri gelmiştir. ${ }^{52}$

8. Fezleke: Bu devir içinde milletin bağlı olduğu eski ve fena adetleri terk etmek için teşebbüsler olmuştur. Bunların en önemlisi I. Ahmed'in koymuş olduğu şehzadelerin saraydan çıkmalarını içeren yasağın I. Abdülhamid tarafından kaldırılmasıdır. Çünkü tahta gelinceye kadar bir kaç kişi dışında insan yüzü görmeyen ve dünyadan habersiz yaşayan şehzadeler dengelerini kaybediyor, içlerinden delirenler oluyordu. İşte bu hürriyetten istifade eden

49 Efdaleddin, Küçük Osmanlı Tarihi, s. 95-97.

50 Efdaleddin, Küçük Osmanlı Tarihi, s. 114-117.

51 Efdaleddin, Küçük Osmanlı Tarihi, s. 127-129.

52 Efdaleddin, Küçük Osmanlı Tarihi, s. 137-138. 
ilk şehzade Sultan Selim kendini iyi yetiştirmiş, dünyadaki gelişmeleri iyi takip etmiş ve islahatperver, yenilikçi bir padişah olmuştur. ${ }^{53}$

9. Fezleke: Osmanlı milleti şanlı bir geçmişe sahip olduğu için daima gözü arkada idi. İlerde yapılması gereken birçok şey olduğu halde bunu takdir edemiyordu. Yenilik namına ne yapılmak isteniyorsa ahali derhal buna teşebbüs edenlere düşman kesiliyordu. Oysa ilerlememiz için terakkiyatı kabul etmek gerekiyordu. Yenilik, hem manen hem de maddeten olacaktı. Bunları herkese öğretmek ve halkı çağın gereklerine vâkıf kılmak gerekiyordu. Nitekim bir gün geldi, halk önceden taraftar olduğu yeniçerilere Vak'a1 Hayriye'de düşman oldu, onları yok etmek isteyen hükümete destek verdi. Neden? Çünkü bunu gerekli gördü. Artık kötülüğü herkes anlıyordu. Fikirler işte böyle kavrayarak değişirse gerçek inkılâp olur. Osmanlı devleti bu suretle inkılâp devrine girmiş oluyordu. ${ }^{54}$

10. Fezleke: Tanzimat Fermanı, eskiden var olup da Vak'a-i Hayriye'de ve daha sonraki zamanlarda yıkılan bütün kaidelerin yerine medeniyete ve asra, siyaset hükümlerine uygun bir şekilde yapılması gereken şeyleri vaat ediyordu. Osmanlı devleti, bundan sonra reforma çalışarak gerçekten bir devlete yakışacak şekil almıştı. ${ }^{55}$

Efdaleddin Bey'in eserin genelindeki değerlendirmeleri gözden geçirildiğinde, devletlerin hayatını canlı bir organizmanın evrelerine benzeten İbn Haldun'un yaklaşımını benimsediği anlaşılır. Ancak onun da, tıpkı Kâtip Çelebi, Naîmâ ve Ahmed Cevdet Paşa gibi, söz konusu nazariyeyi Osmanlı devleti için düşündügüünde İbn Haldun'un mutlak determinizminden ayrıldığı hissedilir. Çünkü henüz hayatta olan devletin geleceğinden doğal olarak ümitli olmak zorundadır.

Bu husus dışında, eserin özellikle fezleke kısımlarındaki değerlendirmelere bakıldığında, Efdaleddin Bey'in Osmanlı tarihini sosyolojik bakımdan çok iyi tahlil ettiği anlaşılmaktadır. Son olarak Efdaleddin Bey'in eserinin şeklî yönünün yanı sıra, anlatımda sergilediği tavırla da ilk Osmanlı tarihi ders kitabının yazarı Ahmed Vefik Paşa(ö.1891)'dan önemli ölçüde etkilenmiş olduğunu belirtmek gerekir.

4. Târîh-i OsmânîHaritaları, Karabet Matb., Istanbul 1329/191 1, I+22 s.

Osmanlı Devleti'nin kuruluşundan, yazarın zamanına kadarki mülkî değişiklikleri gösteren haritalardan oluşmaktadır. Efdaleddin Bey, eserin başındaki "İfâde" başlığı altında şunları kaydetmiştir:

53 Efdaleddin, Küçük Osmanlı Tarihi, s. 153-156.

54 Efdaleddin, Küçük Osmanlı Tarihi, s. 176-178.

55 Efdaleddin, Küçük Osmanlı Tarihi, s. 188-190. 
"Fenn-i târihe birçok ulûm ve fünûnun yardımı olduğu bâ-husûs coğrafyanın bu muâvin fenler arasında en mühim bir kısım teşkil eylediği şüphesizdir... Avrupa'da ehemmiyet-i mahsûsa ile nazar-1 dikkate alınan tarihî haritalara müteallik olarak pek çok eser vücuda getirilmiş ise de târîh-i Osmânî için yeni başlamış olan bu nev' teşebbüsât henüz şâyân-1 dikkat semere-i muvaffakıyet husûle getirememişdir... Târîh-i Osmânîyyeye âid olmak üzere harâit-i târihiye tanzimi teşebbüsatı matlub netâyici verememek i'tibâriyle şu tasvîr edilen suretler dairesinde kalmışdır. Fi'l-vâki' bunlar arasında vesâitin fikdânından dolayı dehâ meşîme-i tasavvurda iken olmuşlar olduğu gibi az çok emek sarf olunduğu halde nâ-temâm kalmışlar dahî mevcuddur..."

Efdaleddin Bey'in bu sözlerinden, onun tarihe yardımcı ilim dallarından oldukça profesyonel bir şekilde yararlandığı, özellikle coğrafya ile yakından ilgilendiği anlaşılmaktadır. Tarihî atlaslar ve yararları konusunda Avrupa'daki gelişmeleri takip ettiği görülen Efdaleddin Bey, bu küçük çalışmasıyla adeta kendinden sonrakilere örnek olmak istemiş, söz konusu tarzda eserler vücuda getirmenin önemine dikkat çekmiştir. Hemen bütün eserlerini, milletine karşı vefa borcu ödeme zihniyetiyle kaleme aldığı hissedilen Efdaleddin Bey, birtakım eksiklikler nedeniyle eserini istediği gibi hazırlayamadığını, bazı haritaların da yarım kaldığını belirtmiştir. Ancak kanaatimizce önemli olan, Efdaleddin Bey'in o zaman için yeni bir çalışma tarzı olan bu eseri milletinin istifadesine sunmuş olmasıdır.

5. Abdurrahman Şeref Efendi (Tercüme-i Hâli, Hayat-ı Resmiye ve Husûsiyesi), Halk Matb., Istanbul 1345/1926,38 s.

Efdaleddin Bey'in, "Kırk seneden fazla huzurunda feyz aldı̆̆ım bir mün'im-i irşâdkârım" dediği hocası Abdurrahman Şeref (1853-1925)'in vefatı sonrası kaleme aldığı eseridir. Memleketin yetiştirdiği en büyük şahsiyetlerden biri olan hocasının aziz hatırasına, bir eser kaleme almayı vicdani sorumluluk kabul ettiğinden bahseden Efdaleddin Bey, eserine İsmail Muştak'ın onun vefatı üzerine yazdığı ve "Seksen yaşında bir pîr-i edeb, yarım asırlık bir hayat-1 irfân, bir kaç bin şâkird ile dört neslin hocası; işte bugün kara toprağa tevdî’ ettiğimiz Abdurrahman Şeref!" sözleriyle başlayan duygu yüklü makalesine yer vererek giriş yapmıştır. Daha sonra Abdurrahman Şeref Bey'in muhtemelen resmî kayıtlardan yararlanarak resmî tercüme-i halini sunmuş, çocukluk zamanına, ailesine ve tahsiline dair bilgiler vermiş, Mülkiye Mektebi müdürlüğü öncesi ve sonrasındaki faaliyetlerinden bahsetmiştir. Onun ilim-irfan âlemine hizmetlerinin özellikle Mülkiye Mektebi müdürlüğüne tayininden (1879) sonra başladığını belirten 
Efdaleddin Bey, on altı yıllık müdürlüğünün bu mektebin tarihi için gerek eğitim-öğretim kalitesinin sürekli yükselme göstermesi, gerekse dönemin hastalığı olan jurnalcilikle mektebin dış etkilere maruz kalmasının önlenmesi bakımından çok önemli olduğunu belirtmiştir. Daha sonra Mekteb-i Sultânî müdürlüğü yıllarını anlatmış olan yazar, II. Meşrutiyet'den sonra Abdurrahman Şeref Bey'in maârif nazırlığına geçmesini, mektebin himayetkar bir idareciyi kaybı, hükümetinse büyük bir devlet adamı kazanması olarak değerlendirmiştir. Ancak yeni görevlerinin onu tedris hayatından uzaklaştırmasını ise üzüntü ile ifade etmiştir.

Yaklaşık kırk yıl boyunca Abdurrahman Şeref Bey ile hemen her hafta mutlaka görüştüğünü, zor zamanlarında hep yanında olduğunu belirten Efdaleddin Bey, eserinin son kısımlarını hocasının kişiliği ve onunla ilgili hatıralara ayırmıştır. Dolayısıyla burada kaydettikleri, gerek Abdurrahman Şeref Bey'in hayatı ve kişiliğine, gerekse o dönemin siyasi ve kültürel hayatına ilişkin birincil kaynak niteliği taşıması bakımından son derece önemlidir.

Yazar eserini, Üsküdar Mevlevîhanesi Şeyhi Ahmed Remzi Efendi ve Üsküdarlı Talat Bey tarafından Abdurrahman Şeref Bey'in vefatı münasebetiyle yazılan şiirlerle bitirmiştir.

Efdaleddin Bey'in bu biyografik eseri, gerçekten büyük bir Osmanlı ilim ve devlet adamı olan hocasının tanınmasına vesile olduğu gibi, hastahanedeki son günleri dâhil olmak üzere asla yalnız bırakmamış olmasıyla kendisinin de ne kadar ilme ve ilim adamına hürmetkâr, vefakâr bir kişiliğe sahip olduğunu göstermesi bakımından dikkat çekicidir.

\section{B. Makale ve Bildirileri:}

1. "Bir Vesîka-i Müellim", Târîh-i Osmânî Encümeni Mecmuası (TOEM), C. l, cüz: 4, 1 Teşrîn-i evvel 1326 (1910),s. 201-210.

Bu makale Efdaleddin Bey'in, 1 Nisan 1326 / 14 Nisan 1910 tarihinde yayın hayatına başlayan Târîh-i Osmânî Encümeni'nin yayın organı Târîh-i Osmânî Encümeni Mecmuası'ndaki ${ }^{56}$ ilk yazısıdır. O, bu mecmuada daha ilk sayılarından itibaren olgun ve değerli etüdler neşretmiştir.

Efdaleddin Bey bu yazısında, 891/1486 yılı ortalarında İstanbul'a bir elçi göndererek yardım talebinde bulunan Endülüs Müslümanlarını konu edinmiştir. Özellikle elçinin Osmanlı padişahına ulaştırdığı, Ebû Bekâ künyesiyle bilinen Salih b. Şerif'e ait kaside, yazının ana malzemesidir. Kasidenin asıl metnini ve özetle tercümesini okurlara sunmuş olan Efdaleddin Bey,

56 Bu mecmua hakkında bkz. Müjgan Cunbur, "Tarih-i Osmanî Encümeni Mecmuası”, Türk Ansiklopedisi, Ankara, 1981, XXX, 461-462. 
böylece Arapların İspanya'da oluşturdukları İslâm medeniyetinin yüceliklerine dikkat çekmiş, Kral Ferdinand'ın 897/1491 yılındaki istilasından sonra ise İspanya'da meydana gelen insanlık dışı manzarayı anlatmıştır. Vermiş olduğu bilgilere göre Araplar İspanya bölgesine girdiklerinde sergiledikleri tavırla daha ilk yıllardan itibaren orayı cennete çevirmişler; darulfünûnlar, hastaneler, kütüphaneler ve medreseler inşa ederek bölgeyi her yönden mamur hale getirmişler; ayrım yapmadan bütün insanları ülkenin nimetlerinden yararlandırmışlardır. Oysa Hristiyanlar, özellikle 1465-1485 yılları arasında Müslüman Araplara tam bir felaket dönemi yaşatmışlar, onların elinin değdiği her şeyi yakıp yıkmışlar, işkenceler yapmışlardır. Bu süre zarfında civardaki Müslüman memleketlerden yardım talep edilmiş ancak yardım gelmemiştir. İşte Osmanlı padişahına Gırnata ulemasınca yapılan imdat çağrısı, söz konusu dönemin artık dayanılmaz bir şekilde devam ettiği 1486 yılı ortalarında olmuştur. Ancak Osmanlı devletince Endülüs Müslümanlarına yardım edilmek istendiyse de doğrudan bir yardım gerçekleşmemiştir. Buna gerekçe olarak deniz kuvvetinin o kadar uzak bir yerde başarı gösteremeyecek durumda olması ve o sırada Cem Sultan'in ${ }^{57}$ Avrupa'da bulunması gösterilmiştir. Çünkü Osmanlı yönetimi, bu safhada Hristiyan âlemine karşı yapılacak bir hareketin, mevcut siyasî ilişkileri son derece olumsuz etkileyeceğini düşünmüştür. ${ }^{58}$

Endülüs Müslümanlarının bölgedeki hizmetlerine pek çok örnek vermiş olan Efdaleddin Bey, yaklaşık 800 yıllık hâkimiyetleri zarfında diğer din mensuplarına kötü muamelede bulunmayan Endülüs müslümanlarının, gördükleri baskı ve zulmü haketmemiş olduklarını belirtmiştir.

Bu çalışmada oldukça hissî bir anlatım sergilemiş olan Efdaleddin Bey, aktardı ̆̆ı bilgileri hangi eserlerden aldığına ilişkin bir ifade kullanmamıştır. Ancak bir vesileyle bahsettiği Ahmed b. Muhammed et-Tilimsânî el-Makkarî (1584-1632)'nin Nefhu't-Tîb min Ğusni'l-Endelüs er-Ratîb adlı eserinden fazlaca yararlandığı anlaşılmaktadır. Zira bu eser Endülüs'deki Müslümanların son zamanlarını anlatan yegâne eserdir. ${ }^{59}$

2. "Alemdar Mustafa Paşa", TOEM, c. II, cüz: 10, 1 Teşrîn-i evvel 1327 (1911), s. 595-603; c. II, cüz: 11, 1 Kânûn-ı evvel 1327 (1911), s. 684696; c. II, cüz: 12, 1 Şubat 1327 (1911), s. 731-740; c. III, cüz: 13, 1

57 Cem Sultan hakkında bkz. Mahmut H. Şakiroğlu, “Cem Sultan”, DİA, İstanbul, 1993, VII, 283284.

58 Endülüs-Osmanlı münasebetleri hakkında bkz. Mehmet Özdemir, "Endülüs", DİA, İstanbul, 1995, C. XI, s. 216.

59 Bkz. Ramazan Şeşen, Müslümanlarda Tarih-Coğrafya Yazıcıllğı, İstanbul, 1998, s. 348. 
Nisan 1328 (1912), s. 796-808; c. III, cüz: 14, 1 Haziran 1328 (1912), s. 841 -856; c. III, cüz: 15, 1 Ağustos 1328 (1912), s. 905-923; c. III, cüz: 16, 1 Teşrîn-i evvel 1328 (1912), s. 969-976; c. III, cüz: 17, 1 Kânûn-ı evvel 1328 (1912), s. 1033-1046; c. III, cüz: 18, 1 Şubat 1328 (1912), s. 1097 1112 ; c. IV, cüz: 19, 1 Nisan 1329 (1913), s. $1161-1176$; c. IV, cüz: 20, 1 Haziran 1329 (1913), s. 1232-1245; c. IV, cüz: 21, 1 Ağustos 1329 (1913), s. 1304-1327.

Efdaleddin Bey'in on iki sayı süren yazı dizisi şeklindeki bu makalelerin toplamı yaklaşık 170 sayfa olup, esasında müstakil bir kitap hacmindedir. Mecmuanın 9. cüzünde, III. Selim dönemi sslahat çalışmalarının büyük emektarı Alemdar Mustafa Paşa'nın hayatına ilişkin ayrıntılı bir çalışmanın gelecek sayıdan itibaren başlayacağı duyurulmuştur.

Böyle bir çalışmayı, Yedikule'den geçecek ikinci bir demiryolu hattının inşa edildiği esnada, fedakâr bir ıslahatçı olarak kadir ve kıymeti bir kat daha beliren Alemdar Mustafa Paşa'nın kemiklerinin, layık olduğu bir ihtifal ile Gülhane Parkı'nın girişi karşısındaki Zeynep Sultan Camii haziresine nakli münasebetiyle gündeme almış olan Târîh-i Osmânî Encümeni Mecmuası yöneticilerinin, bu şehid devlet adamının hayatını kaleme almayı Efdaleddin Bey'den istedikleri anlaşılmaktadır. ${ }^{60}$

Alıntı yaptığı kaynakları büyük oranda belirtmiş olan Efdaleddin Bey'in bu çalışmayı hazırlarken ağırlıklı olarak Ahmed Âsım (ö.1819) ve Cevdet Paşa (ö.1895)'nın tarihleri ile Şânizâde(ö.1826)'nin Târîh-i Şânizâde, Mustafa Nuri Paşa(ö.1890)'nın Netâyicü'l-Vukûat, Tayyar-zâde Atâullah Ahmed (ö.1877)'in Atâ Tarihi, Mustafa Necib Efendi (ö.1831)'nin Vak'a-i Selimiye, Mehmed Süreyya (ö.1909)'nın Sicill-i Osmânî, Hafız Hızır Efendi (ö.1864)'nin Tarih-i Enderûn adlı eserlerinden yararlandığı görülmektedir.

Efdaleddin Bey'in bu çalışması Alemdar Mustafa Paşa hakkında daha sonra yapılan çalışmaların temel kaynağı olmuştur. Nitekim Cumhuriyet döneminde onun hakkında bir kitap kaleme almış olan İsmail Hakkı Uzunçarşıl11, ${ }^{61}$ Efdaleddin Bey'in söz konusu çalışmasından önemli ölçüde yararlanmıştır.

Efdaleddin Bey de, III. Türk Tarih Kongresi'ne sunmuş olduğu bildiride Uzunçarşılıyı isim vermeden, Alemdar Mustafa Paşa adlı çalışmasındaki belge kullanımında gösterdiği maharetten dolayı övmüştür. ${ }^{62}$

60 Bkz. "Alemdar Mustafa Paşa Hakkında Birkaç Söz", TOEM, c. II, cüz: 9, 1 Ağustos 1327/1911, s. 529.

61 Bkz. İsmail Hakkı Uzunçarşılı, Meşhur Rumeli Ayanlarından Tirsinikli İsmail, Yılıkoğlu Süleyman Ağalar ve Alemdar Mustafa Paşa, TTK Yay., İstanbul, 1942.

62 Bkz. Efdaleddin Tekiner,"Tarihimizde Noksanlar Nasil Tamamlanabilir?”, III. Türk Tarih Kongresi Bildirileri (Ankara 15-20 Kasım 1943), Ankara, 1948, s. 467. 
Efdaleddin Bey'in diğer çalışmalarında olduğu gibi bunda da konuya hâkim bir tavır sergilediği görülmektedir. Yararlandığı eserlerden edindiği bilgileri son derece güzel kompoze etmiş ve anlaşllır üslup sergilemiştir. Olaylara müdahil olan kişiler arasında geçmiş olan diyalogları çalışmasına ustalıkla yerleştirmiş, zaman zaman bilinmeyen kelime, kavram ve mekanlarla ilgili notlar düşerek okuyucuyu aydınlatmaya çalışmıştır. Özellikle çeşitli kalıntılara bakarak olayların geçtiği mekanların III. Selim devrindeki halini tasvir etmesi, okuyucuya dönemin siyasî ve sosyal hareketliliğini anlatırken deyim yerindeyse görsel bir tablo çizmesi onun dikkate değer hassasiyetlerindendir.

Çalışmanın sonunda Cevdet Paşa'nın Alemdar Mustafa Paşa için kaydettiği "Devlet ve milleti hakkında niyeti hayırlı ve himmeti pek âlî bir zât olduğundan bu vechile felâketzede olduğuna teessüf olunur" sözüne yer veren Efdaleddin Bey, Necib Asım Bey'den temin ettiği Alemdar Mustafa Paşa destanıyla (1223/1808) makalesini sona erdirmiştir. Bu vesileyle masallar, şiirler, millî türküler gibi destanların da bir milletin ruh halini yansıtması açısından önemli ölçüde tarihî malzeme içerdiklerine dikkat çekmiş, Alemdar Mustafa Paşa destanını buna örnek göstermiştir.

3. "İstiklâl-i Osmanî Tarih ve Günü Hakkında Tetkîkat", TOEM, c. V, cüz: 25, 1 Nisan 1330, (1914), s. 36-48.

Efdaleddin Bey bu çalışmasını, Osmanlı Devleti'nin istiklal gününü tespit etmek ve bu günün millî bayramlardan biri kabul edilerek, her yıl kutlanma arzusu doğrultusundaki ihtiyaca binaen kaleme aldığını belirtmiştir. İstiklâl gününün tam olarak bilinmesi konusu ortaya çıkınca, Maarif Nezareti'nin, belgelere dayalı bir çalışma yapılması için 28 Kânûn-ı Sânî 1329 tarihli ve numaralı tezkire ile bu işi Târîh-i Osmânî Encümeni başkanlığına havale etmiş olduğundan bahseden Efdaleddin Bey, encümenin de kendisini görevlendirdiğini belirtmiştir.

Efdaleddin Bey, çalışmasında öncelikle o zamana kadar yazılmış olan tarihlerdeki bu konuyla ilgili kayıtlara yer vermiştir. Alıntı yaptığı eserler sırasıyla şunlardır:

Bedreddin el-Aynî (1361-1451), Ikdü'l-Cümân

Beyâtî Şeyh Mahmud, Câmi'-i Cem Âyîn

İdris-i Bitlisî (ö.1521), Heşt Bihişt

Derviş Mehmed b. eş-Şeyh Ramazan, Sübhetü'l-Enbiyâ ve Tuhfetü'lÜbedâa $\hat{a}^{33}$

63 Babinger bu eserin ismini Subhatu'l-Ahbâr ve Tuhfetü'l-Ahyâr şeklinde vermiş̧ir. Bkz. Osmanl Tarih Yazarları ve Eserleri, Çev. Coşkun Üçok, Ankara, 2000, s. 78. 
Lütfî Paşa (ö.1564), Tevârîh-i Âl-i Osmân

Nişancizâde Mehmed b. Ahmed (1560-1631), Mir'âtü'l-Kâinât

Hoca Sadeddin Efendi (ö.1599), Tâcü't-Tevârîh

Âlî (ö.1599), Künhüll-Ahbâr

Hasan Bey-zâde (ö.1636), Telhîsu Tevârîh

Abdülaziz Karaçelebî-zâde (1591-1658), Ravzatü'l-Ebrâr

Müneccimbaşı (ö. 1702), Sahâyifu'l-Ahbâr

Osman-zâde Ahmed Tâib (1660-1724), Hadîkatu'l-Mülûk

Abdurrahman Münîb, Fihrisü'd-Düvel

Şemdânî-zâde Süleyman Efendi (ö.1779), Mür'itt-Tevârîh

Hayrullah Efendi 1817-1866, Tarîh-i Devlet-i Aliyye-i Osmâniyye

Resmî Salnâme, sene: 1330

Kâtip Çelebi (1609-1657), Takvîmü't-Tevârîh

Mustafa Paşa (1824-1890), Netâyicu'l-Vukûât

Bunların genel mütâlaasından anlaşıldığına göre 699 yılı, Osmanlı Devleti'nin istiklâl tarihi olarak kabul edilmiştir. Bazı tarihçiler ise bu tarihten önce bazı bağımsızlık alametlerini dikkate alarak, istiklâlin 688 ve 697 yıllarında gerçekleşmiş olduğunu yazmışlardır. Ancak bu tarihleri rivayet edenler oldukça azdır. Efdaleddin Bey, istiklal tarihinin Selçuklu Sultanı Alâaddin'in saltanatının sona ermesiyle irtibatlandırılarak 699 olarak kabul edilmesinden sonra, halledilmesi gereken asıl meselenin, yılın değil günün tayini olduğunu belirtmiştir. Zira Câmi'-i Cem Âyîn'deki bir kayıttan, uç gazilerinin Osman Han'ı oy birliğiyle başa getirdikleri gün, el öpme ve kımız sunumunun yapıldı̆̆ı resmî bir tören icra edildiğinin anlaşıldığına dikkat çeken Efdaleddin Bey, ancak söz konusu kayıtta bu törenin tam olarak hangi günde yapıldığının belirtilmediğini ifade etmiştir.

Efdaleddin Bey'e göre istiklâl günü işte o gündür. Ancak bu hususu aydınlatacak belgeler yoktur. İstiklâl gününe dair mevcut olan yegâne resmi kayıt Salnâme'deki 4 Cemâziyel-evvel 699/27 Ocak 1300 tarihi ise de bunun 1263/1847 tarihli Salnâme'den ${ }^{64}$ başka yerde görülmemesi, en önemlisi daha önceki tarih kitaplarında yer almaması çözülmesi gereken asıl problemdir.

Bu çalışma esnasında Efdaleddin Bey ilginç bir yöntem de uygulamış ve matbuata ilân vererek, bu konuda elinde belge bulunan veya bilgisi olanların kendisine ulaşmalarını duyurmuştur. Neticede kendisine yalnız iki mek- 
tup ulaşan Efdaleddin Bey bunları değerlendirmiş,tekrar Salnâme'ye dönmüş ve başka herhangi bir resmi dayanak bulunmadığı için oradaki kaydı kabul etmek gerektiği sonucuna varmıştır.

Efdaleddin Bey konunun bir de İlhanlı ve Selçuklu kaynaklarına bakılarak araştırılması gerektiğini belirterek, bu makalesine ek yeni bir çalışma hazırlayacă̆ını ifade etmiştir. Ancak araştırmamız esnasında bu konuda yeni bir çalışmasına rastlamadık.

Bu izahlara göre, Cumhuriyet dönemi tarihçilerinin bu zamana kadar nakledegeldikleri 1299 yıll, sadece merasim gününün 699 yılının ilk üç ayında yani Muharrem, Safer ve Rebîülevvel aylarında olması halinde doğrudur ki, buna dair bir kaynak veya belge yoktur.

4. "Memâlik-i Osmaniye'de Tıbâatin Kıdemi", TOEM, c. VII, cüz: 40, 1 Teşrîn-i evvel 1332 (1916), s. 242-249.

Efdaledin Bey bu makalesini, Târîh-i Osmânî Encümeni Mecmuası'nda yayınlanan Macar müsteşrik Dr. Karacson (İmre) ${ }^{65}$ ve Mistakidis Efendi'nin $^{66}$ Osmanlı Devleti'nde matbaanın kuruluşunu ve İbrahim Müteferrika'yı konu alan yazıları üzerine kaleme aldığını belirtmiştir. Özellikle Mistakidis Efendi'nin makalesinde İbrahim Müteferrika'nın matbuatını açıklamakla birlikte, ondan evvel Osmanlı memleketinde matbaacılı̆̆ın mevcud olduğuna dair verdiği bilgiler Efdaledin Bey'in dikkatini çekmiştir.

Çünkü Mistakidis, miladî 15. asırda İstanbul'da matbaacılığın yapılmakta olduğunu ve önce II. Bayezid'in, daha sonra da I. Selim'in 1515 yılında yenilediği bir irâde üzerine matbaa ile meşgul olanların idam tehdidiyle bu işi yapmaktan menedildiklerini yazmıştır.

Efdaleddin Bey bu ifadeler üzerine, İbrahim Müteferrika'dan önceki matbaacılığı tetkik etmiştir. Yapmış olduğu araştırmayla gerek İstanbul'da gerekse memleketin diğer yerlerinde matbaacılı̆̆ın daha önceden tesis edilmiş olduğunu, Avrupa ülkelerinin bazılarında da Doğu dillerinde kitaplar basıldığını, özellikle Ebuzziya Tevfik Bey’in matbaacılığa dair yazdığı makalelere göre Hristiyanlığa dair pek çok eserin Arapça ve Farsça basılmış olduklarını beyan etmiştir.

Ancak II. Bayezid ve I. Selim'in bir irâdeyle matbaa ile uğraşmayı yasakladıkları yolundaki iddiayı reddetmiştir: Şöyle ki, eldeki Divan-1 Hümâyûn kayıtlarına göre 961/1553 tarihinden önceki defterlerin mevcud olmaması

65 “ibrahim Müteferrika”, TOEM, c. I, cüz: 3, 1 Ağustos 1326 (1910), s. 178-185.

66 "Hükümet-i Osmânîye Tarafından İlk Te'sîs Olunan Matbaa ve Bunun Neşriyatı", TOEM, c. I, cüz: 5, 1 K. Evvel 1326 (1910), s. 322-328 ve c. II, cüz: 7, 1 Nisan 1327 (1911), s. 451-455. 
sebebiyle zikrolunan idam tehdidini içeren fermanı bu kayıtlar içinde bulmak imkansızdır. Böyle bir fermanın kesin olarak varlı̆̆ belirlenmedikçe söz konusu padişahların iddia edildiği gibi sert bir tavır gösterdikleri kabul edilemez.

Efdaleddin Bey, İbrahim Müteferrika'dan önce Türkçe kitap basıldı̆̆ 1 şeklindeki iddiayı ise, Mustafa Paşa'nın Netayicü'l-Vukûat adlı eserindeki (c. III, s.130) bir kaydı değerlendirerek ele almıştır. Buna göre III. Murad zamanında, bir yabancının Türkçe harflerle kitap basmak ve böylece gümrük vergisinden muaf tutulmak üzere ruhsat taleb etmesi söz konusudur. Mustafa Paşa, kendisine izin veren 996/1587 tarihli fermanın metnini, esbâk şeyhülislâm Hüsâm Efendi'deki bir kitabın dibâcesinde gördügünü, fakat kitabın ismini ve hangi ilim dalına dair olduğunu hatırlayamadığını yazmıştır.

Efdaleddin Bey yine bu hususla ilgili olarak, Ali Emîri Efendi'de bahsi geçen fermanın bulunduğu matbu bir kitap gördüğünü ve bu kitabı vesika olarak mütalaa etmek gerektiğini belirtmiştir. Nerede ve ne zaman basıldığına dair üzerinde bir kayıt bulunmayan, ancak Nasıruddin et-Tûsîye ait olduğu kaydedilmiş olan Arapça eserin, ilk sahifesinde III. Murad'ın fermanı vardır. Efdaleddin Bey söz konusu fermanın tam metnine makalesinde yer vermiştir. Mustafa Paşa'nın eserinde bahsettiği fermanla bu eserde yer alan fermanın aynı tarihli olduğunu belirten Efdaleddin Bey, bir yılda aynı konuda iki ferman verilemeyeceğine, dolayısıyla ele geçen fermanın diğeriyle aynı olduğuna hükmetmiştir. Bahsi geçen kitabın Emîrî Efendi'nin kurduğu Millet Kütüphanesi'nin Cârullah Efendi kısmında olduğunu belirten Efdaleddin Bey, söz konusu fermanın Türkçe eser basılma hususunda 996/1587 yılı öncesi için ilk vesika olarak kabul edilebileceğini, fakat bununla, Osmanlı memleketinde Türkçe eser basımı gerçekleştirildiğine kanaat getirilemeyeceğini ifade etmiştir.

Daha sonra Osmanlı memleketinde Arapça ve Farsça olarak basılmış kitaplara örnekler veren Efdaleddin Bey, aktarmış olduğu verilere göre İbrahim Müteferrika'dan önce Osmanlı memleketinde matbaanın varlığının kesin olduğunu, ancak Türkçe kitap basımının 1726'daki teşebbüsden önce gerçekleşmemiş olduğuna hükmetmiştir. Arapça ve Farsça eser basılmasının ise İbrahim Müteferrika'nın şan ve himmetine gölge düşürmeyeceğini belirten Efdaleddin Bey, Türkçe kitap basımının İbrahim Müteferrika ile başlamış olduğunun kabul edilmesi gerektiği sonucuna ulaşmıştır.

Yararlandığı eserleri araştırmanın içerisinde bir bir zikretmiş olan Efdaleddin Bey, elde ettiği verileri kullanmadaki kabiliyetiyle örnek ve yararlı bir çalışma ortaya koymuştur. 
5. "Osmanlılarda Vatan Muhabbeti", Mülkiye Mecmuası, c. II, Nr: 10, 1 Teşrîn-i sânî 1325 (1909), s. 37-43.

Efdaleddin Bey'in, bu yazısında insanlarda doğuştan gelen vatan edinme ve vatanı sevme duygusunu öncelikle psikolojik olarak tahlil ettiğini görüyoruz. Vatan sevgisinin oluşumunu öz olarak "İnsanların meskenlerinde, meskenlerinin mecmûu olan memleketlerinde; vesâit-i maîşetlerini tedarik eyledikleri yerlerinde menfaatleri arttıkça oraya irtibatları da o nisbette artarak sâir menfaatle memleketine, mevcudiyetine muhabbeti koyulaşır. Şu hal hadariyetle daha celî bir rû-nümâ olur (ortaya çıkar)" şeklinde ifade etmiş olan Efdaleddin Bey'in, söz konusu ifadelerinden İbn Haldun'un devletlerin oluşumunda etkin bir unsur olarak kabul ettiği asabiyet nazariyesinden hareketle Osmanlılarda vatan muhabbetini ele almaya çalıştı̆̆ 1 görülmektedir. ${ }^{67}$

Tarihin her döneminde bütün toplumların mesken tuttukları yerlere bir sevgi duyduklarını ve vatanları için kanlı müdafaalarda bulunduklarını belirten Efdaleddin Bey, özellikle vatanperverlikleriyle meşhur Ispartalıları ve Romalıları örnek vermiştir.

Müslüman toplumlarda da, Hz.Peygamber'in "vatan sevgisi imandandır" sözüyle vatan sevgisinin dinî bir vecibe olarak görüldüğünden bahsetmiş, yedi oğlunu şehid vermiş olan Medineli Afrâ Hatun'un metanetini de bir örnek olarak zikretmiştir.

Osmanlılarda da vatanperverlik anlayışının "taşına toprağına kurban olmak" sözüyle geliştirilmiş ve yerleştirilmiş olduğundan bahseden Efdaleddin Bey, Orta Asya'daki vatanlarından ayrı düşmüş olan Osmanlıların, yüreklerinde hissettikleri vatan acısıyla Küçük Asya'ya gelip de vatan edindikleri yerlere yerleşince, oralara hem eski vatanlarının muhabbeti yerine hem de göç acısının verdiği gayretten doğan bir sevgiyle bağlandıklarını belirtmiştir. Nesil değiştikçe ecdattan teslim aldıkları toprakları artık öz malları addederek sahiplendikleri gibi yeni fetihlerle sahip oldukları yerlere de gönülden bağlanmışlardır. Vatanın her köşesine bir kutsiyet vererek, onu sevmeyi millî ve itikadî bir görev haline getirmek için ziyaretgâhlar, namazgâhlar, türbeler ve mabedlerle donatmışlardır. Osmanlı vatanı kuvvetli bir zincir ile her Osmanlının ruhunun derinliklerine bağlanmıştır.

$\mathrm{Bu}$ hissin nazariyattan ibaret olduğunu zannetmenin bir hata olduğundan bahseden Efdaleddin Bey, altı yüz yıllık siyasi bir mevcudiyetin her noktasından geçmişine doğru bakıldığında, bu muhabbet duygusunun daima var olduğu ve çeşitli şekillerde tekrar ettiğinin görüldüğünü belirtir.

67 Bkz. İbn Haldun, Mukaddime, Çev. Zakir Kadiri Ugan, İstanbul, 1997, I, 352-355. 
Osmanlı tarihinden çeşitli kahramanlık örnekleri vermiş olan Efdaleddin Bey, bunlardan ecdadın yadigâr bıraktı̆̆ı vatanın nasıl bir azim ve gayretle muhafaza edileceğine dair ders çıkarmak gerektiğini ifade etmiştir. Vatanını sevmeyenleri nankör evlatların analarını tanımamaları kabilinden bir fürûmâyelik (soysuzluk) göstermekle itham eden Efdaleddin Bey, bunun ahlakî yönden bir zillet olduğunu vurgulamıştır.

Bir insanın evinin kendisinin olmasıyla olmaması bir midir?

Vatansızlık kadar elim bir dağdağa-i hayat (ıstıraplı hayat) var mıdır?

İşte bu sorularla yazısını tamamlayan Efdaleddin Bey, son olarak "Bunun için biz, vatanperverlikle şöhret-yâb olan Osmanlılar, Osmanlı vatanını nasıl sevmek, nasıl muhâfaza etmek lâzım geldiğini takdîr etmeliyiz. Gerek müdâfaa gerek tecâvüz için kullanılacak esbâbın yalnız silahdan ibâret olduğu zamanlardan hayli mübâadet edilmişdir(uzaklaşılmıştır). Birbiriyle müsâdemeye(savaşmaya)hazırlanan milletlerin evvelâ galebeyi (azgınlığı) mekteblerde ihdâr ettikleri devirdeyiz. Vatanımızın, mübârek vatanımızın muhâfazası uğrunda sarf edeceğimiz gayretleri hep o yeni esas üzerine ibtinâ ettirmeliyiz." sözleriyle ilimle mücehhez olan bir milletin azminin kır1lamayacağına, hukukunun çiğnenemeyeceğine ve vatanının taarruza maruz kalmayacağına dikkat çekmiştir.

Efdaleddin Bey'in bu yazıyı diğer ilmî çalışmalarından farklı olarak çok daha hissî bir üslubla kaleme aldığını ve yazıyı kaleme alış nedeniyle ilgili herhangi bir açılamada bulunmadığını görmekteyiz. Ancak onun böyle bir yazıyı, 13 Nisan 1909'da gerçekleşen ve II. Abdülhamid'in tahttan indirilmesiyle sonuçlanan 31 Mart Vak'ası akabinde ortaya çıkan siyasî atmosferin etkisiyle kaleme aldığı düşünülebilir. Böylece muhtemelen millî birlik ve beraberliğe her zamankinden daha fazla ihtiyaç olduğuna dikkat çekerek, bir mesaj vermek istemiştir.

6. "İstanbul'da Kapalı Çarşı", Türkiye Turing ve Otomobil Kurumu Belleteni, S. 88, Mayıs 1949, s. 6-8. (Ingilizcesi: "The Great Bazar of Istanbul", TTOK Belleteni,S. 92, Eylül 1949, s. 15-19.

Kapalıçarşı'nın Bizans devrinden kalma olup olmadığı yönündeki tartışmalarla yazısına başlamış olan Efdaleddin Bey, İstanbul'un fethini müteakip Fatih Sultan Mehmed'in bu çarşıyı inşa ettirmiş olduğunun Fatih vakfiyesinden anlaşıldığ 1 gibi, dönemin tarihçilerinden Tursun Bey (ö.1499'dan sonra) ve Bizans tarihçisi Kritovolus'un verdiği bilgilerin de bunu doğruladığını belirtmiştir. Ayrıca binanın kemer tuğlaları ve payelerdeki taş kesmelerinin emsaline birçok Türk yapısında rastlanan Türk işçiliğini gösterdiğini ifade etmiştir. Bu kısa açıklamadan sonra bazı belgelere dayanarak çarşının 
ilk haline ek olarak yapılan genişletmelerden, deprem ve yangınlarla uğradığ 1 değişikliklerden bahseden Efdaleddin Bey, çarşının hem geçmişteki yapısını hem de zamanındaki halini çarşı-sokak adları ve mimarî özellikleriyle anlatmaya çalışmıştır.

Efdaleddin Bey'in bu yazısı, Kapalıçarşı Dergisi'nce çarşıyı konu edinen nadir çalışmadan biri olarak takdim edilmiştir. Dergideki ifade şu şekildedir: “Orhan Veli'nin 'Kapalıçarşı kapalı kutu' sözü şairane bir ifade ama gerçekten Kapalıçarşı tarihi açısından doğru bir saptama. İstanbul'un yüzyıllardır ticarî hayatının merkezi, kültürle, ticaretin iç içe girdiği, yüksek sanat eserlerinin üretildiği, alınıp satıldığı bir mekan olan Kapalıçarşı hakkında yapılmış çalışmalar iki elin parmaklarından az. Çelik Gülersoy, Efdaleddin Tekiner, Orhan Erdenen gibi kişilerin çalışmaları ve çarşıyı daha çok ticarî yönde tanımlayan birkaç ufak kitapçığın dışında Türkçemizde bir çalışma bulmak mümkün değil.”68

İfade edilen önemi nedeniyle daha önce The Great Bazar of Istanbul ${ }^{69}$ adıyla müstakil olarak basılmış olan bu kısa fakat özlü çalışmanın,TTOK'un 1955'deki Genel Kurulunda tekrar neşredilmesine karar verildiği görülmektedir. $^{70}$

7. "Osmanlı Ihtilâlleri", Mülkiye Mecmuası, c. II, Nr: 11, 1 Kânûn-ı Evvel 1325, s. 45-49; c. II, Nr: 12, 1 Kânûn-ı Sânî 1325, s. 52-57; c. II, Nr: 13, 1 Şubat 1325, s. 53-56; c. III, Nr: 14, 1 Mart 1326, s. 60-64; c. III, Nr: 15, 1 Nisan 1326, s. 56-60; c. III, Nr: 16, 1 Mayıs 1326, s. 55-58; c. III, Nr: 17, 1 Haziran 1326, s. 44-49; c. III, Nr: 18, 1 Temmuz 1326, s. 49-56; c. III, Nr: 19, 1 Ağustos 1326, s. 48-60; c. III, Nr: 20, 1 Eylül 1326, s. 55-64.

$\mathrm{Bu}$ yazı dizisinde Efdaleddin Bey, ihtilâllerin oluşum süreci üzerinde sosyo-psikolojik açıdan durduktan sonra, Osmanlı tarihinde zaman zaman meydana gelmiş olan isyan ve ayaklanmaların ihtilâl olarak değerlendirilip değerlendirilemeyeceğini tartışmıştır. Çünkü her ihtilâl bir isyanla başlar, ancak her isyan ihtilâlle sonuçlanmaz. Bir isyanın ihtilâle dönüşmesi için kişisel veya oldukça dar bir çevrenin problemi olmayıp, kamuoyunun büyük bir kesimini ilgilendirmesi gerekir. Her milletin tarihinde olduğu gibi Osmanlıların tarihinde de ihtilâl devirleri olduğunu belirten Edaleddin Bey, ihtilâllerin kendine has oluşum özellikleri olması nedeniyle ayrı ayrı ele alınması gerektiğini ifade etmiştir. Osmanlı tarihinin incelenmesi gereken bu

68 Bkz. Kapalıçarşı Dergisi, S. 2. (http://www.kapalicarsi.com/2tr/konular/yangin.htm. 24.01.2004)

69 İstanbul, 1949.

70 Türkiye Turing ve Otomobil Kurumu'nun 5 Nisan 1955 Genel Kurul Raporu, İstanbul, 1955, s. 9. 
önemli meselesinin, hakkıyla açıklanabilmesi için devletin yapılanmasının çok iyi bilinmesi gerektiğine dikkat çeken Efdaleddin Bey, konuyu özellikle Yeniçeri ocağının her tür hoşnutsuzlukta kullanılması üzerine bina etmiştir. Bu askerî kurumun başta devlet erkânından olan kimselerce iç siyasete alet edilmesinin, geçmişte fetih hareketlerinde gösterdiği başarının yok olmasına yol açmış olduğunu belirtmiş, Fatih devrinden sonra müdahil oldukları her olayı ayrı ayrı ele almıştır.

Efdaleddin Bey'in sık sık "tevarîhde tafsîlatı görülen" ifadesine göre bu çalışma için pek çok tarih kitabından yararlanmış olduğu anlaşılmaktadır. Ancak o, yararlandığı bazı eserleri ise ismen belirtmiştir. Dipnotlardaki kayıtlara göre çoğunlukla;

Hoca Sa'deddin Efendi (ö.1599)'nin Tâcü't-Tevârîh,

Mehmed Hemdemî (ö. 1657)'nin Fihrist-i Şâhân (Solakzâde Tarihi),

Müneccimbaşı (ö.1702)'nın Sahayifü'l-Ahbâr,

Hayrullah Efendi (1817-1866)'nin Târîh-i Devlet-i Aliyye-i Osmâniyye adlı eserlerini kullanmıştır.

Ana konu olarak Osmanlı tarihindeki ihtilâl nitelikli olan ve olmayan isyanların işlendiği çalışma, genel olarak her padişahın kişisel özellikleri ve dönemlerinin dikkate değer olayları hakkında ciddi değerlendirmeler içermesi bakımından son derece önemlidir. Yararlanılan eserlerin çok iyi etüd edildiği anlaşılan çalışmada, Efdaleddin Bey kişisel kanaatlerini oldukça ilmî bir üslupla ortaya koymuştur.

8. "Tarih", Mülkiye Mecmuası, c. I, Nr: 1, 1 Kânûn-ı Sânî 1324, s. 61-64; c. I, Nr: 2, 1 Şubat 1324, s. 63-64; c. I, Nr: 3, 1 Mart 1325, s. 61-64; c. I, Nr: 4, 7 Nisan 1325, s. 63-64; c. l, Nr: 5, 1 Mayıs 1325, s. 61-64; c. l, Nr: 6, 1 Haziran 132 5, s. 44-48; c. II, Nr: 7, 1 Ağustos 1325, s. 57-61; c. II, Nr: 8, 1 Ey/ül 1325, s. 60-62; c. II, Nr: 9, 1 Teşrîn-i evvel 1325, s. 59-64.

Efdaleddin Bey'in, tarih bilimi ve Osmanlı tarihçiliği üzerine müstakil olarak kaleme almış olduğu bir çalışmadır. Onun tarih, tarihçilik ve özellikle Osmanlı tarihçiliğ̈ine bakış açısını net bir şekilde yansıtmaktadır. Osman11 tarihlerine olan derin vukûfiyetini göstermesi bakımından da son derece önemlidir. Efdaleddin Bey, makalesinde belirttiği görüşlerde, kimlerin etkili olduğu hususunda herhangi bir açıklamada bulunmamıştır. Ancak XIX. yüzyılda Avrupa'da tarih felsefesi alanındaki gelişmelerden haberdar olmaması imkânsızdır. Özellikle çalışması boyunca tarih yazıcılığında muhakemenin ön planda tutulması gerektiğini israrla vurgulaması, Annales ekolünün ${ }^{71}$

71 Annales ekolü hakkında ayrıntılı bilgi için bkz. Halil İnalcık, "The Impact of the Annales 
tarihî olayların değerlendirilmesinde savunduğu sebep-sonuç bağlantısı kurma ve zamanın rölatifliğini göz önünde bulundurma gibi hususlarla doğrudan ilişkilidir. Efdaleddin Bey'in, bu yazıyı mükemmel bir Osmanlı tarihi yazılması gerektiği fikrinden hareketle kurulan Târîh-i Osmânî Encümeni'nin aynı doğrultudaki çalışmasına katkıda bulunmak niyetiyle kaleme almış olduğu anlaşılmaktadır. Çünkü çalışmasının başında bir miktar tarihin konusu ve önemi üzerinde durduktan sonra, Osmanlı Devleti'nin kuruluşundan itibaren kaleme alınmış olan gerek resmî gerekse özel tarihçilerin tarih kitaplarını genel bir değerlendirmeye tabi tutmuş, özellikle vakanüvislerin yazmış oldukları tarihlerin son derece yetersiz olduklarından bahsetmiştir. Bunun için de, mükemmel bir Osmanlı tarihi yazılmadan önce nelere dikkat edilmesi gerektiğine dikkat çekerek görüşlerini kaydetmiştir. Buradaki görüşlerine, daha ayrıntılı bir şekilde onun tarihçiliği ile ilgili kısımda yer vereceğiz. Ancak bir cümleyle belirtmek gerekirse Efdaleddin Bey, toplumsal yapısından başlayarak, siyaset, ticaret, hukuk, sanayi, yaşam tarzı, örf âdetler, bilim ve sanata varıncaya kadar her hususun geçmişteki tasvirini ortaya koyacak bir Osmanlı tarihi yazılması gerektiği görüşündedir.

9. "Tarihimizde Noksanlar Nasıl Tamamlanabilir?", III. Türk Tarih Kongresi Bildirileri (Ankara 15-20 Kasım 1943), Ankara, 1948, s. 460-469.

Osmanlı tarihçiliğine bir öz eleştiri getirdiği bu bildirisi, Efdaleddin Bey'in görmüş olduğu eksiklikler ve sunmuş olduğu öneriler bakımından dikkate değerdir. Onun tarih ve tarihçilik anlayışını doğrudan yansıttığı için bu çalışmaya ilişkin değerlendirmeye, "Tarihçiliği" başlığı altında yer vermeyi uygun buluyoruz.

10. "Nedim ve Damad ibrahim Paşa'nın Mezarları", IV. Türk Tarih Kongresi Bildirileri (Ankara 10-14 Kasım 1948), Ankara, 1952, s.174-177.

Efdaleddin Bey bu bildiride iki mezar taşı üzerindeki manzum tarihlerden yola çıkarak, yanlış bir anlamayı gidermiştir. Bu yanlış anlamanın içeriği şu şekildedir: Karacaahmet mezarlığında yan yana iki mezar vardır. Mezar taşlarının birindeki manzum tarihten (1143) ve taştaki "Nedim Ahmed Efendi" ibaresinden hareketle, bu mezarın Şair Nedim Ahmed Efendi'ye ait olduğu; yanındaki mezardaki "Mâder-i müşfikâsı âzim-i şehrah-1 bekâ" ve "Saliha kadına câ ide bihişti mevlâ" ifadelerinden dolayı da diğer mezarın

School on Ottoman Studies and New Findings", Rewiew, S. 1, Binghamton, 1978, s. 69-96; Georg G. Iggers, Yirminci Yüzyılda Tarihyazımı, Çev. Gül Çağalı Güven, İstanbul, 2003, s. 5165; Peter Burke, Fransız Tarih Devrimi: Annales Okulu, Çev. Mehmet Küçük, Ankara, 2002. 
onun annesine ait olduğu hususunda bir zan oluşmuş, hatta bu mahalde âbide kurulması düşünülmüş ve buradaki tarihî mezarlar kaldırılmıştır.

Efdaleddin Bey ise mezar taşlarındaki ifadelerden ve Şair Nedim'in İstanbul'daki ikamet mahallinin oraya uzaklığından hareketle, söz konusu mezarın Şair Nedim'e değil, Müderris Nedim Ahmed'e, diğer mezarın da o müderrisin annesine ait olduğunu ortaya koymuştur. Tarihçi İsmet Efendi'nin kayıtlarıyla da Şair Nedim'in mezarının gerçek yerinin Ayaspaşa mezarlığında olduğunu tespit etmiştir. Ayrıca bu vesileyle, vakfiyeler mütehassısı Nuri Ebussuud-zâde'nin bulduğu vesikalarla Damad İbrahim Paşa'nın mezarlarını tespit etmiştir. Buna göre, Patrona Halil isyanı sonunda feci bir şekilde öldürüldüğü bilinen Nevşehirli İbrahim Paşa'nın, cesedinin bazı parçaları Şehzâde camii karşısındaki kendi medrese ve caminin haziresine, bazı parçaları da yine gizlice Süleymaniye'deki Defterdar Şemseddin Cenderî türbesi karşısına gömülmüştür.

Mezar taşlarındaki kitâbelerin, tarihi aydınlatmak için çok önemli birer vesika olduklarının inkar edilemeyeceğini belirtmiş olan Efdaleddin Bey, bu çalışma ile mezar taşlarının tarihî değerlerine ilişkin güzel bir örnek vermiştir.

\section{C. İslâm Türk Ansiklopedisi'ndeki Maddeleri}

Eşref Edip, İsmail Hakkı İzmirli, Kâmil Miras ve Ömer Rıza Doğrul'dan oluşan bir yazı heyetinin idaresi altında, Âsâr-ı İlmiyye Kütüphanesi'nin yayın organı olarak neşre başlamış olan bu ansiklopedide ${ }^{72}$ Efdaleddin Bey; Âmedci, Âmedî, Âsar-1 Atîka, Âsitâne, Âsıme, Âşûra (Sarayda Âşûra Tevzii Merasimi), Âteş-i Rûmî, Âteş Kayı̆̆ı, Âteş Mehmet Paşa, Âteş Oku, Â'yan, Âyîn, Âyineli Kavak (Aynalı Kavak Kasrı) ve Âzadlu maddelerini yazmıştır.

Efdaleddin Bey'in ansiklopedideki maddelerini ayrı ayrı değerlendirmenin, çalışmamızın hacmini hayli zorlayacağı açıktır. Bir bütün halinde baktığımızda Efdaleddin Bey'in daha çok Osmanlı dönemindeki çeşitli kurum, idarî görev, tarihî kişilik ve yapılarla ilgili maddeleri yazmış olduğunu görmekteyiz. Oldukça akademik bir üslupla kaleme almış olduğu bu maddeler, özellikle eski İstanbul hayatına ilişkin kıymetli bilgiler içermektedir. Çünkü o, madde sonlarındaki bibliyografyalara bakıldığında yazma ve matbu pek çok eserden yararlandığı gibi, özel hatıratlar kullanmış, zaman zaman da kişisel tecrübe ve gözlemlerine dayalı bilgiler vermiştir.

72 İstanbul'da 1940-1948 yılları arasında çıkan, ancak "A" maddeleri tamamlanmadan yayını duran bu ansiklopedinin mahiyet ve hedefi ile ilgili geniş bilgi çin bkz. İslâm Türk Ansiklopedisi, İstanbul, 1940, s. 9-16; Ayhan Aykut, "İslâm Türk Ansiklopedisi", DİA, İstanbul, 2003, XIII, 5758. 


\section{TARIHÇILIĞi}

Efdaleddin Bey'in uzun hayatında tarihle meşguliyetinin ayrı bir yeri vardır. İdarî görevleri ve diğer bazı sivil toplum kurumlarındaki aktif faaliyetlerinin yanı sıra, onun öğretmenliklerine dair kaydettiklerimizi hatırlayacak olursak, döneminin vazgeçilmez tarih hocalarından birisi olduğunu rahatlıkla söyleyebiliriz. Bir makale hacmindeki çalışmamızda yer verebildiğimiz kadarıyla üzerinde durduğumuz eserleri göstermektedir ki, Efdaleddin Bey, tarih hocası, tarih araştırıcısı ve tarih yazarlı̆̆ı gibi üç vasfı zatında toplamış bir kişidir. Bir hayli çalışma kaleme almış olmasına rağmen Efdaleddin Bey’i yakından tanıyanlar, onun yazmaktan çok anlatmayı tecih ettiğinden bahsederek, birikimine göre eserlerini oldukça az bulduklarını belirtmişlerdir. ${ }^{73}$

Efdaleddin Bey'de tarih ilgisinin tam olarak ne zaman ve kimin etkisiyle başladığını tespit edemiyoruz. Ancak kuvvetle muhtemeldir ki bu konudaki ilk etki öncelikle ailesinden gelmiştir. Çünkü ailesi İstanbul'da tanınmış ve kültürlü bir ailedir. Sarayla yakın diyaloğu olan kültürlü bir babadan, geçmiş zamanlara ilişkin pek çok tarihi hikâye, Osmanlı sarayının içinde ve dışında meydana gelmiş pek çok siyasî, kültürel ve sosyal içerikli anekdot dinlemiş olması muhtemeldir. Daha sonra ise kendisinin de zaman zaman ifade ettiği gibi Mülkiye mektebindeki derslerinden itibaren Abdurrahman Şeref Bey'in tarihçi kişiliği, tarihi gerek yazma gerekse anlatmadaki maharetiyle Efdaleddin Bey'in üzerinde oldukça etkili olduğu söylenebilir. Bu etkiyle, daha genç yaşlarından itibaren tarih hocalığını kendisine asıl meslek seçmiştir. Mülkiyede hukuk ve Galatasaray'da tarih hocalığında bulunuşu, onun kısa zamanda titiz bir tarih hocası ve araştırmacısı olarak yetişmesine yardımcı olmuştur. Daha 30 yaşlarında iken de Dârulfünûn'a Osmanlı tarihi hocası olan Efdaleddin Bey, Birinci Dünya Harbi başlarına kadar bu vazifede bulunmuş, Abdurrahman Şeref Bey'in reisi bulunduğu Târîh-i Osmânî Encümeni'nde daimi üye olarak yer almıştır.

Bu gelişmeler onun tarihçiliğine de ciddi anlamda etki etmiştir. Zira bu görevlerden sonra üstlenmiş olduğu sorumluluğun bilinciyle hareket ederek, tarih alanında ilmî üslupla yazılar kaleme almış, dersleri için ciddi ders notları hazırlamış ve bunları kitaplaştırmıştır. Encümenin ana gayesi olan mükemmel bir Osmanlı tarihi yazımı için de, zamanına kadar Osmanlı tarihçiliğinde gördüğü eksiklikleri dile getirerek, yeni vücuda getirilecek kitapta nelere dikkate edileceğini ortaya koymuştur.

73 H. Y. Şehsuvaroğlu, "Merhum Efdaleddin Tekiner”, s. 5; S. Eyice, “Tekiner, Efdaleddin”, D. B. Istanbul Ansiklopedisi, VII, 235; 
Efdaleddin Bey'in, tarihle meşgul olmayı kendisine bir hayat tarzı olarak seçmiş olduğu anlaşılmaktadır. Nitekim emekliliği sonrasında uzunca bir süre tarih dersleri vermeye devam etttiği gibi, vefatına kadar Türk Tarih Kurumu üyeliği ve İstanbul Eski Eserleri Koruma Derneği başkanlığ gibi onu doğrudan tarihle içi içe tutan görevlerden de uzak kalmamıştır.

Anladı̆̆ımız kadarıyla Efdaleddin Bey, tarihe hizmet etmeyi tarihî bir görev olarak görmüştür. Nitekim çalışmalarının çoğunda didaktik bir tarz sergileyen Efdaleddin Bey, tarihini bilmeyenlerin ana-babalarını bilmeyenler gibi olduklarını defalarca vurgulayarak, tarih öğretiminin gerekliliğine ve önemine dikkat çekmiştir. Ancak ona göre bir milletin gerçek tarihi sadece savaşlar ve fetihler tarihi değil, kültür ve medeniyet tarihidir. Maalesef Osmanlı tarihçileri çoğunlukla tarihin siyasî kısmından ve meşhur olaylarından, bazen de idarî değişikliklerden bahsederek, sosyal yapıyı oluşturan unsurlara dair çok az bilgi vermişlerdir. Bu içtimaî unsurlar kültür, sanat, örf-âdet ve daha pek çok hususları kapsadığı halde, eldeki yazılarda ve kitaplarda pek az yazılmış olduğu için, haklarında yeterli bilgi edinmek kesin olarak mümkün değildir. Bu itibarla Efdaleddin Bey'in ifadesiyle "Türk Osmanlı" ${ }^{14}$ tarihinin yazılmış olan vekâyiinin de birçok kısımları eksik bulunmaktadır. Üstelik tarihçilerin çoğu, vekâyinamelerinde inşâ mahareti göstermek için ifadeyi feda etmiş, anlaşılmaz hale sokmuş; birçoğu şehnâme tarzındaki eserlerle işi meddahlığa kadar ileri götürmüş; içtimaî unsurlara dair sayısız hadiseler geçtiği halde bunları önemsiz sayarak bilinmesi gereken hususları ihmal etmişlerdir. Dolayısıyla Türk Osmanlı medeniyet tarihi namına yapılacak araştırmalar malzeme eksikliği nedeniyle verimsiz kalmaktadır. ${ }^{75}$

Efdaleddin Bey, milletin medenî kudretini tesis eden ilim ve sanat tarihinin, söz konusu bakış açısı nedeniyle yeterince aydınlatılamamış olduğu görüşündedir. "Her şeyin bir tarihinin olması tabiîdir" diyen Efdaleddin Bey, örneğin mimarlı̆̆ın, tabâbetin ve riyâziye gibi fenlerin her birinin birer tarihinin olmasının son derece doğal ve gerekli olduğunu belirtir. Fakat mimarlık tarihi araştırıldığında, mimarbaşılara ait isimlerden başka bir bilgiye sahip olunmadığının görüldüğüne dikkat çeken Efdaleddin Bey, "mimarları bilmekle beraber, bunların çalışma yöntemlerini, sanata vukûfiyetlerini, planlarını tatbik şekillerini bilmek gerekir. Değil sanatın bu teknik işlerini, bazı

74 Osmanlıların son dönemindeki fikri hareketlilik ve akımlar hakkında geniş bilgi için bkz. Yusuf Akçura, Üç Tarz-ı Siyaset, Ankara, 2005.

75 Efdaleddin Tekiner, “Tarihimizde Noksanlar Nasıl Tamamlanabilir?”, III. Türk Tarih Kongresi Bildirileri(15-20 Kasım 1943, Ankara), Ankara, 1948, s. 460-461. 
önemli eserlerin vücuda getirilmesinde ilk olma özelliğine sahip olan üstadlar bile bilinememektedir. Çinili Köşk'ün, ${ }^{76}$ Piyale Paşa Camii'nin mimarı kimdir? ${ }^{77}$ Bayezid Camii'ni yapan üstadın ismi nedir? ${ }^{78}$ Bunları kesin olarak tespit mümkün olamamaktadır." demektedir. ${ }^{79}$

Aynı şekilde tabâbet tarihinde de hekimbaşıların tayinlerine dair kronolojik bilgilerle yetinildiği görüşündedir. Ona göre, devletin şark ve garpta şan salan ordularına sağlık hizmeti veren hekimler, cerrahlar ve şehirlerde halk sağlığı ile ilgilenen üstadların kimler olduğu bilinmediği gibi bunların çalışma usulleri ve neticeleri de bilinmemektedir. Bilinse dahi asıl önemli olan nokta, Türk Osmanlı tabâbetinin ne yolda tahsil edildiği ve ne gibi evreler geçirdiği, tıbbî buluşlara katkısı ve nasıl terakki ettiğidir ki, bunlar hakkında bilgi edinilememektedir. Sanat tarihi için de durum farklı değildir. 600 Seneyi aşan bir mevcudiyeti tezyin etmiş ve beslemiş olan medeniyet eserlerini vücuda getiren deha ve dinamikler meçhuldür. Hatta en çok bilinen tarihî şahıslara dair bilgiler biraz derinleştirilmek istense, sonuç hüsran olacaktır. ${ }^{80}$

Tarihimizin birçok yönden eksik olduğu gibi mevcut kısmının da eksik olduğu görüşünde olan Efdaleddin Bey'e göre, öncelikle arşivlerdeki vesikalar olmak üzere vakfiyeler, mahkeme sicilleri, fetvâlar, mezar taşları, kitâbeler, para ve mühür koleksiyonları, eserler üzerinde bulunan imzalar ve benzeri işaretler, eksiklikleri tamamlayıcı araçlardır. Ancak bunların henüz layıkıyla tetkik edilememiş olmaları söz konusu maksada ulaşmaya engel teşkil etmektedir. Hâlbuki bahsi geçen vesâik yeterli birikime ve kabiliyete sahip kişilerce incelendiğinde pek çok eksiklik giderilebilir. Efdaleddin Bey burada ifade ettiği görüşlerini vakfiye, mahkeme sicil kayd, hüccet, ferman ve kitâbe gibi vesîkalardan birer örnek vererek, bunların tarih ilmi bakımından ne kadar kıymetli olduklarını ortaya koymuştur. ${ }^{81}$ Bu örneklerdeki muha-

76 Mimarı hakkında bilgi olmadı̆̆ına dair ayrıca bkz. Semavi Eyice, "Çinili Köşk", DİA, İstanbul, 1993, VIII, 338; Türkiye'nin Şaheserlerinden Örnekler, haz. Mehmet Özel, Kültür Bak. Yay., Ankara, 1996, s. 108.

77 II.Selim'in damatlarından Kaptan-ı Derya Piyale Paşa (ö.1578)'nın yaptırdığı külliyenin çekirdeğini oluşturan Piyale Paşa Camii'nin kim tarafından tasarlanmış olduğu araştırmacılarca tartışllagelmiştir. Bkz. Tahsin Öz, İstanbul Camileri, TTK Yay., Ankara, 1965, II, 54; Yıldız Demiriz-M.Baha Tanman, "Piyale Paşa Külliyesi", D.B. Ístanbul Ansiklopedisi, İstanbul, 1994, VI, 254.

78 Aynı şekilde bu caminin mimarının kim olduğu bilinmemektedir. Bkz. Tahsin Öz, İstanbul Camileri, Ankara, 1962, I, 33.

79 Efdaleddin Tekiner, “Tarihimizde Noksanlar Nasıl Tamamlanabilir?”, s. 461-462.

80 Efdaleddin Tekiner, "Tarihimizde Noksanlar Nasıl Tamamlanabilir?", s. 461-462.

81 Bkz. Efdaleddin Tekiner, “Tarihimizde Noksanlar Nasıl Tamamlanabilir?”, s. 462-466. 
keme kabiliyetine baktığımızda onun çok önemli bir belge tarihçisi olduğu da ortaya çıkmaktadır.

Efdaleddin Bey'in tarihçilikle ilgili sıkıntıları Cumhuriyet dönemi için ise farklı boyutlardadır. Bunun temel sebebi yazı çeşitlerine ilişkindir. Zira ona göre yazı çeşitlerini bilmek ve okuyabilmek zaruridir. Türk Osmanlı devletinin celî, nesih, sülüs, rik'a dîvanî, divanî kırması, siyâkat, reyhânî, ta'lik, rik'a ve daha bazı yazı çeşitleri olduğu malumdur. Bu yazıların çoğunu okuyabilecek kişi ise hayli azalmıştır. İbare sökülerek hecelenerek okunsa bile mefhumunu anlamak için ibaresinde kullanılan tabirleri ve devrinin tarihî malumatlarıyla ilişkisini kurmak gereklidir. Bunun için elde bulunan vesikaların pek çoğu okunamadığı gibi, içerikleri da anlaşılamamaktadır. Dolayısıyla Efdaleddin Bey'e göre bir tarihçi öncelikle vesikaları okuyabilmek ve anlamak kudretine sahip olmakla birlikte, vesikaların kiymet ve derecelerini de tayin edebilmelidir. Her kağıt vesika olamıyacağı gibi her vesika da neşre değer mahiyette değildir. Vesika tetkikinde bilhassa tarihî kıymet ve mahiyet aramak lazımdır. Örneğin bir hükümdarın mahremi meşru'u olan karısına yazdığı bir iştiyaknâme vesikadır diye neşrolunmuştur ki, bunun tarih ilmine veya memleket işlerine veya sair tarihî bahislere katiyen taalluku olamadığı için kimseye bir faydası yoktur. ${ }^{82}$

Daha önce 1916 yılında oluşturulan Vesâik-i Tarihiyye Tasnîf Encümeni'nde görev yaparak, Osmanlı arşivini tasnif çalışmalarına katkıda bulunduğunu belirttiğimiz Efdaleddin Bey, tarihî belgelerin kullanımı kadar, çok iyi bir şekilde tasnif edilerek araştırmacıların hizmetine sunulması noktasında da oldukça hassastır.

Ona göre Cumhuriyet devrinden önceki zamana ait olan kısım, genel arşivden ayrilmak suretiyle tarihe mal edilmeli ve en selahiyetli makam olan Tarih Kurumu'nun kontrolüne bırakılmalıdır. Zira sahipsizlikten dolayı yabancı memleketlere kilo ile evrak satıldığı zamanlar da olmuştur.

Efdaleddin Bey daha önce belirttiğimiz gibi, Osmanlı belgelerinde kullanılmış olan başta siyâkat ve dîvânî gibi yazı türlerini, çok az kişinin bilmesinin tehlikeli bir durum olduğu görüşündedir. Çözümü ise bu yazı türlerinin ve vesikacılığın, iyi bilen şahıslarca yeni nesle öğretilmesinde görmüştür. Nitekim bu tecrübeyi vaktiyle Fransa'nın da yaşamış olduğundan bahseden Efdaleddin Bey, büyük ihtilalden sonra kilise ve manastırların kapanması üzerine 18. asır âlimlerinin tarihî tetkikata devam edebilmeleri için, Latin dilini ve Ortaçağ ilimlerini bilen gençler yetiştirmeleri maksadıyla Ecole Nationale des Chartes adlı okulu kurmuş olduklarını belirtmiştir. Efdaleddin 
Bey'e göre programında paleografi, diplomatik, hukuk tarihi, arşiv tasnifi ve Ortazaman arkeolojisi gibi dersleri bulunan; hedefi arşivist-paleograf yetiştirmek olan böyle bir okula herkesten çok bizim ihtiyacımız vardır. Çünkü harf inkılâbıyla eski yazıların okuyucuları kaybolmaya yüz tutmuş ve eski ilimlere ilişkin bir kısım derslerin öğretimi terkedilmiştir. Türk Osmanlı tarihinin kaynakları olan vesikalar da eski yazı ile yazılmış olduklarından neredeyse okuyucusu kalmamıştır. ${ }^{83}$

Bu noktada Efdaleddin Bey'in şahsının da harf inkılâbından önemli ölçüde etkilenmiş olduğu anlaşılmaktadır. Açıkça herhangi bir yerde ifade etmiş olduğuna rastlamadık, ancak özellikle harf devriminden sonra çok az şey yazmış olduğuna bakılırsa, yeni harflerle yazmaya pek uyum sağlayamadığı anlaşılmaktadır. Fakat kuvvetle muhtemeldir ki eski harflerle kaleme aldığg ve yayınlamadığı pek çok çalışması vardır.

Efdaleddin Bey'in çalışmalarına bir bütün halinde baktığımızda, onun tarihçiliğinde muhakeme gücü ve kabiliyetinin önemli bir yer tuttuğunu görürüz. Çünkü ona göre bilgi olmadan bir şey muhakeme edilemeyeceği gibi, ne kadar engin bilgiye sahip olunursa olunsun tarihî bilgi ve olaylar iyi muhakeme edilmedikçe bir değer ifade etmez. Öz olarak tarih kaynaklarının bağlantılı bir şekilde kritize edilmesinin ve olayların sebep-sonuç ilişkisi içerisinde değerlendirilmesinin kastedildiği bu muhakeme kabiliyetine, Efdaleddin Bey'in örnek alınacak düzeyde sahip olduğunu belirtmek gerekmektedir. Genel olarak her çalışmasında ele aldığı konu hakkında seviyeli bir giriş yapması, konuyu sağlam bir zemine oturtarak tartışması da dikkati çeken üslubudur. Ayrıca her zaman anlaşılır bir anlatım sergilemesi, dili son derece güzel kullanma kabiliyetine sahip olduğunu göstermektedir. Yine onun, günümüz dipnot sistemi tarzında olmasa da, yararlandığı eserleri genel olarak metin içerisinde zikretmeye çalışmasını da, ilmî bir kaygı taşıdığına örnek olarak belirtmek gerekir. Ne var ki Efdaleddin Bey, daha önce de belirttiğimiz gibi yazmaktan çok anlatmayı tercih ettiğinden, özellikle belgelere dayalı çok az çalışma yapmıştır. Özellikle 1928 Harf İnkılâbından sonra birikimini yansıtmakta ciddi bir sıkıntı çektiğini söylemek mümkündür. Zira yayınlanmış çalışmalarının hemen hepsi bu tarihten önce yazmış olduklarıdır.

\section{SONUÇ}

Osmanlı tarihçiliğini çok iyi etüd etmiş biri olarak Efdaleddin Bey, gerek kişisel gayretleri gerekse Târîh-i Osmânî Encümeni, Eski Eserleri Koruma Encümeni ve Osmanlı Arşivi tasnif çalışmaları gibi kolektif çalışmalardaki 
performansıyla, son dönem Osmanlı tarihçiliğinin değerli şahsiyetlerinden biridir. Bu gayretleri Cumhuriyet döneminde de devam etmiştir.

Ömrünün büyük bir kısmını tarih hocalığı ile geçirmiş olması sebebiyle, eserlerinde oldukça didaktik bir tarz sergilemiştir. Çalışmalarında nesnel olma endişesi taşımadığını gördügüüüz Efdaleddin Bey'in, millı̂ tarih bilinci ve hissiyatı son derece güçlüdür. Tarihini bilmeyen bir milletin, babasını bilmeyen insanlar gibi olduklarını belirtmiş olan Efdaleddin Bey, yeni yetişen nesilden, 600 senelik şanlı ve şerefli bir maziye sahip olan ecdadına layık olmalarını istemiştir. Osmanlının adalet, ilim ve sanata değer vererek yükseldiğini, yağmacılıktan yetişmiş göçebe bir millet olmadığını, iktidarın gerekliliklerine vâkıf büyük bir millet olduğunu israrla vurgulamıştır. Hatası ve sevabıyla sahiplendiği Osmanlıyı, Cumhuriyetten sonra da tabiri caizse dilinden düşürmemiş, yazılarında daima "Türk Osmanlı" tabirini kullanmıştır. Yakın dostlarının anlattıklarına göre Osmanlı tarihi ile ilgili konularda her zaman fikirlerine başvurulmuş ve özellikle eski İstanbul hayatına dair sohbetleri zevkle dinlenmiştir.

Efdaleddin Bey'in çalışmalarından, bilimsel tarihçiliği takip etmeye gayret gösterdiği anlaşılmaktadır. Açıkça ifade etmese de İbn Haldun'un Osmanlı tarihçileri ve aydınları üzerindeki etkisinden kısmen o da etkilenmiştir. Osmanlı devletinin devam ve bekâsına ait kanaatleri, daha önce Kâtip Çelebi, Naîmâ, ve Ahmed Cevdet Paşa'nın, İbn Haldun'un mutlak determinizminden ayrılan görüşleri doğrultusundadır. Ayrıca 18. ve 19. yüzyıllarda Batı'da Annales ekolünün başlattı̆̆ı, tarihî olayları sebep-sonuç ilişkisine göre değerlendirme ve bunu yaparken zamanın rölatifliğini göz ardı etmemek gerektiği konusundaki tarihçilik anlayışından da etkilendiği gözlemlenmektedir. Araştırmamızın, Efdaleddin Bey'in çalışmalarını tanıttığımız bölümünde, bu tespiti destekleyen pek çok ifade ve örneğe yer vermiştik.

Son olarak ifade edebiliriz ki, Efdaleddin Bey'in mükemmel bir Osmanlı tarihi yazılması için oluşturulan komisyonda yer alması, Osmanlı tarihçiliğine dair yapmış olduğu kapsamlı eleştirilerde ciddi anlamda etkili olmuştur. Böylece o, daha o dönemden itibaren yeni yetişen tarihçilere, Osmanlı tarihçiliğinin nasıl yapılması gerektiğine ilişkin ufuk çizen önemli tarihçilerden biri olmuştur. 